\title{
Farm nitrogen balances in six European landscapes as an indicator for nitrogen losses and basis for improved management
}

\author{
T. Dalgaard ${ }^{1}$, J. F. Bienkowski ${ }^{2}$, A. Bleeker ${ }^{3}$, U. Dragosits ${ }^{4}$, J. L. Drouet ${ }^{5}$, P. Durand ${ }^{6}$, A. Frumau ${ }^{3}$, N. J. Hutchings ${ }^{1}$, \\ A. Kedziora ${ }^{2}$, V. Magliulo ${ }^{7}$, J. E. Olesen ${ }^{1}$, M. R. Theobald ${ }^{4,8}$, O. Maury ${ }^{5}$, N. Akkal ${ }^{6}$, and P. Cellier \\ ${ }^{1}$ Aarhus University, Department of Agroecology, Denmark \\ ${ }^{2}$ Institute for Agricultural and Forest Environment, Poland \\ ${ }^{3}$ Energy Research Centre of the Netherlands, The Netherlands \\ ${ }^{4}$ Centre for Ecology and Hydrology, Scotland, UK \\ ${ }^{5}$ INRA, Environnement et Grandes Cultures, France \\ ${ }^{6}$ INRA, Soil, Agro-hydrosystems Spatialisation, France \\ ${ }^{7}$ Institute for Agriculture and Forest Systems in the Mediterranean, Italy \\ ${ }^{8}$ Technical University of Madrid, Spain
}

Correspondence to: T. Dalgaard (tommy.dalgaard@agrsci.dk)

Received: 30 June 2012 - Published in Biogeosciences Discuss.: 21 July 2012

Revised: 22 October 2012 - Accepted: 23 October 2012 - Published: 20 December 2012

\begin{abstract}
Improved management of nitrogen $(\mathrm{N})$ in agriculture is necessary to achieve a sustainable balance between the production of food and other biomass, and the unwanted effects of $\mathrm{N}$ on water pollution, greenhouse gas emissions, biodiversity deterioration and human health. To analyse farm N-losses and the complex interactions within farming systems, efficient methods for identifying emissions hotspots and evaluating mitigation measures are therefore needed. The present paper aims to fill this gap at the farm and landscape scales. Six agricultural landscapes in Poland (PL), the Netherlands (NL), France (FR), Italy (IT), Scotland (UK) and Denmark (DK) were studied, and a common method was developed for undertaking farm inventories and the derivation of farm $\mathrm{N}$ balances, $\mathrm{N}$ surpluses and for evaluating uncertainty for the 222 farms and 11440 ha of farmland included in the study.

In all landscapes, a large variation in the farm $\mathrm{N}$ surplus was found, and thereby a large potential for reductions. The highest average $\mathrm{N}$ surpluses were found in the most livestock-intensive landscapes of IT, FR, and NL; on average $202 \pm 28,179 \pm 63$ and $178 \pm 20 \mathrm{~kg} \mathrm{~N}^{-1} \mathrm{yr}^{-1}$, respectively. All landscapes showed hotspots, especially from livestock farms, including a special UK case with large-scale landless poultry farming. Overall, the average $\mathrm{N}$ surplus from the land-based UK farms dominated by extensive sheep and
\end{abstract}

cattle grazing was only $31 \pm 10 \mathrm{~kg} \mathrm{~N}^{-1} \mathrm{yr}^{-1}$, but was similar to the N surplus of PL and DK $(122 \pm 20$ and $146 \pm 55 \mathrm{~kg}$ $\mathrm{N}$ ha $^{-1} \mathrm{yr}^{-1}$, respectively) when landless poultry farming was included.

We found farm $\mathrm{N}$ balances to be a useful indicator for $\mathrm{N}$ losses and the potential for improving $\mathrm{N}$ management. Significant correlations to $\mathrm{N}$ surplus were found, both with ammonia air concentrations and nitrate concentrations in soils and groundwater, measured during the period of $\mathrm{N}$ management data collection in the landscapes from 2007-2009. This indicates that farm $\mathrm{N}$ surpluses may be used as an independent dataset for validation of measured and modelled $\mathrm{N}$ emissions in agricultural landscapes. No significant correlation was found with $\mathrm{N}$ measured in surface waters, probably because of spatial and temporal variations in groundwater buffering and biogeochemical reactions affecting $\mathrm{N}$ flows from farm to surface waters.

A case study of the development in $\mathrm{N}$ surplus from the landscape in DK from 1998-2008 showed a $22 \%$ reduction related to measures targeted at $\mathrm{N}$ emissions from livestock farms. Based on the large differences in $\mathrm{N}$ surplus between average $\mathrm{N}$ management farms and the most modern and $\mathrm{N}$ efficient farms, it was concluded that additional $\mathrm{N}$-surplus reductions of $25-50 \%$, as compared to the present level, were realistic in all landscapes. The implemented $\mathrm{N}$-surplus 
method was thus effective for comparing and synthesizing results on farm $\mathrm{N}$ emissions and the potentials of mitigation options. It is recommended for use in combination with other methods for the assessment of landscape $\mathrm{N}$ emissions and farm $\mathrm{N}$ efficiency, including more detailed $\mathrm{N}$ source and $\mathrm{N}$ sink hotspot mapping, measurements and modelling.

\section{Introduction}

Nitrogen $(\mathrm{N})$ is essential for agricultural production, but is also a key driver of environmental pollution, and can result in $\mathrm{N}$ concentrations in air and water exceeding critical limits for eutrophication (de Vries et al., 2011), significant greenhouse gas emissions (Alcamo and Olesen, 2012), biodiversity deterioration (Dise et al., 2011), and severe human health impacts (Brink and van Grinsven, 2011).

With agriculture responsible for most of the humaninduced changes to the global N-cycle (Galloway et al., 2003), a global population increase of about 88 million people per year (United Nations Populations Fund, 2011), and a rapid growth in the global middle class with higher food consumption rates, an efficient, low $\mathrm{N}$-surplus agricultural sector becomes increasingly important. Consequently, the balance between $\mathrm{N}$ input and output has been recognised as one of the key indicators for the development of sustainable agricultural systems (European Environmental Agency, 2005; OECD, 2008).

In the last few decades, the European Union has launched initiatives to mitigate the effects of $\mathrm{N}$ from agriculture, with a special focus on the most intensively farmed agricultural regions in Central- and Western Europe (Oenema et al., 2011). The effectiveness of these N-mitigation measures, especially related to the National Emissions Ceilings Directive (2001/81/EC), the Nitrates Directive (1991/676/EC) and the Water Framework Directive (2000/60/EC), are undisputable (Kronvang et al., 2008; Volk et al., 2009; Hansen et al., 2011). However, there are considerable differences in $\mathrm{N}$ surpluses and $\mathrm{N}$ losses between countries and regions (van Grinsven et al., 2012; Hansen et al., 2012), and there is a lack of knowledge concerning the effects of spatial variation in $\mathrm{N}$ surplus at the watershed (Bartoli et al., 2012; Ulrich and Volk, 2010) and landscape levels (Drouet et al., 2012). Previous studies have focused on larger watersheds (Bartoli et al., 2012; Billen et al., 2012; Lassaletta et al., 2012) or regions (Leip et al., 2008; Neumann et al., 2011), and are typically based on statistics and publicly-available geo-databases rather than empirically collected data. These studies provide valuable insight into the consequences of $\mathrm{N}$ hotspots at these regional scales, but there is a lack of knowledge concerning the interactions between the local farm management and the natural processes in specific landscapes with agricultural Npollution hotspots (Cellier et al., 2011; Dalgaard et al., 2011; Hewett et al., 2009).
In 2006, the pan-European research project NitroEurope was launched (Sutton et al., 2007; NitroEurope, 2012). This included a landscape-scale component that aimed to provide new knowledge on $\mathrm{N}$ losses from agricultural landscapes, closing parts of the information gap between plot/field-scale experiments, and regional/national scale $\mathrm{N}$ statistics (Dalgaard et al., 2009; Bende-Michl et al., 2011). The authors of the present paper and the related research institutions all contributed to this landscape component of NitroEurope, including the inventory of six study landscapes with significant farm-related $\mathrm{N}$-emission hotspots, and experiences from previous national research projects (Bouraoui et al., 1999; Dalgaard et al., 2002a, b; Dragosits et al., 2002, 2006; Hansen, 2004; Molenat et al., 2008).

In overview, the objectives of the present paper are to

- Compare farm-scale crop and livestock production data and the descriptions of the biophysical environment in the six case study landscapes in Poland, the Netherlands, France, Italy, Scotland and Denmark

- Analyse the farm N-balance results, the differences between the input and output components of the $\mathrm{N}$ balances, and the derived $\mathrm{N}$ surpluses across landscapes (the $\mathrm{N}$ surplus is defined as the different between the sum of inputs and the sum of outputs in the N-balance)

To these ends the final objective is to document the method developed to inventory farm data and calculate $\mathrm{N}$ balances in European landscapes. Moreover, we discuss the effects of Nsurplus hotspots and the farming system heterogeneity within the landscapes as well as between landscapes. Finally, we assess the use of farm N-balance calculations and modelling for the independent verification of measured $\mathrm{N}$ concentrations in the environment, and the evaluation of possible measures to increase agricultural $\mathrm{N}$ efficiency and reduce $\mathrm{N}$-emissions from agricultural landscapes.

\section{Materials and methods}

\subsection{Study landscapes}

As illustrated in Fig. 1, the study included farm data from six landscapes in Poland (PL), the Netherlands (NL), France (FR), Italy (IT), Scotland (UK), and Denmark (DK), all with $75 \%$ or more of the total area taken up by agricultural land use (Fig. 2).

Based on local knowledge of relevant sites for the study of agriculture-related $\mathrm{N}$ hotspots, and perspectives for further elaboration of existing studies and data collections (Bienkowski et al., 2009; Hansen, 2004; Molenat et al., 2004), information on general land use and farming systems characteristics was collected. Compared with the average percentage of Utilised Agricultural Area for all 27 EU countries, which was $40.1 \%$ in 2007 (Eurostat, 2011), all six 

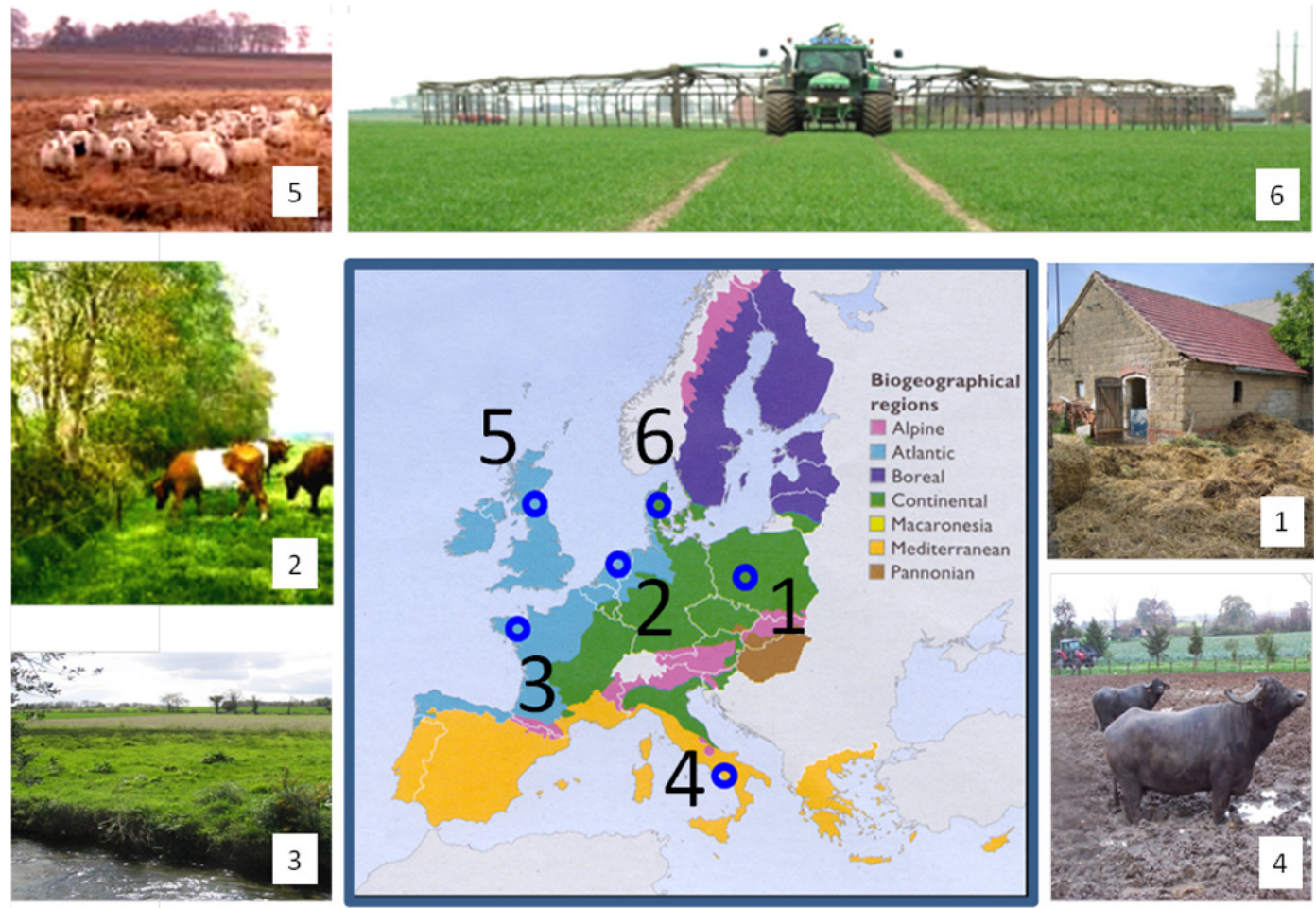

Fig. 1. Location of the six study landscapes: (1) Turew, PL; (2) The North Friesian Woodlands, NL; (3) Naizin, FR; (4) Piana del Sele, IT; (5) Southern Scotland, UK; and (6) Bjerringbro, DK; superimposed onto the European Environmental Agency's (2002) biogeographical regions of Europe. The photographs show important farming systems in these landscapes (clockwise from bottom left corner, and with number corresponding to the actual landscape): intensive cattle grazing on wet, permanent grasslands in France and the Netherlands, sheep grazing on rough grassland in Scotland, pig slurry application with trailing hose to winter cereals in Denmark, farmyard manure heap outside a traditional farmhouse in Poland, and a water buffalo paddock in Italy.

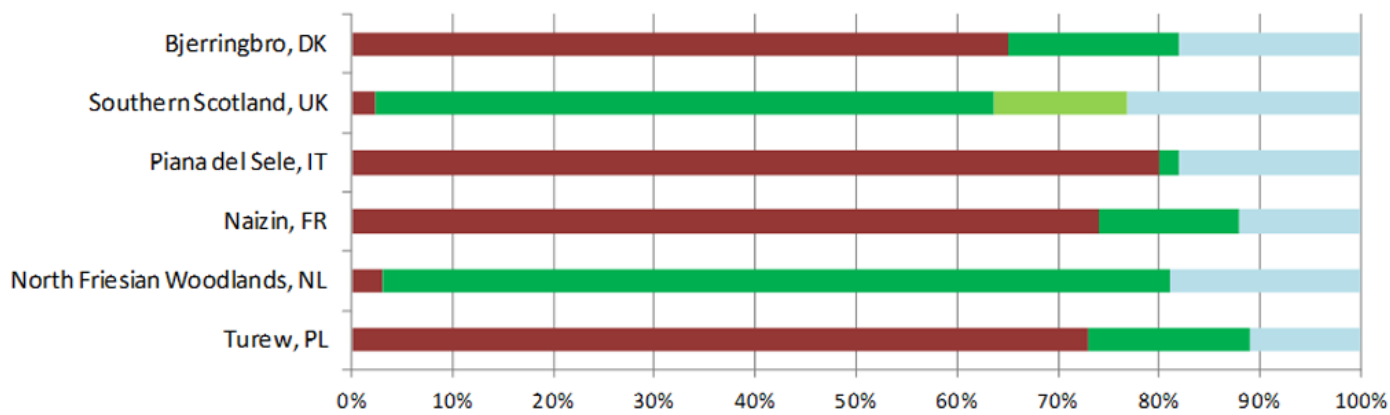

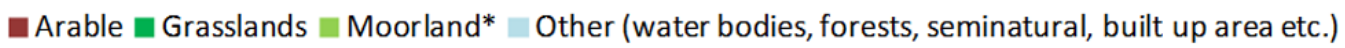

Fig. 2. Overall land use distribution in the six study landscapes 2007-2009. * Moorland and rough grassland account for about one fifth of the grassland in the Southern Scotland study area and are only extensively grazed.

landscapes have a very high proportion of their land under agriculture, dominated by grasslands in the Scottish and Dutch areas, and arable crops in the other landscapes (Fig. 2). The highest proportion of agricultural land use was found in Turew (PL) and Naizin (FR) (around 90\%), whereas it was around $80 \%$ in NFW (the North Friesian Woodlands, NL), Piana del Sele (IT) and Bjerringbro (DK), and about $75 \%$ in the Scottish landscape (UK), where large areas of grass- land and moorland is grazed extensively. Other types of land use were mainly small woodlands, hedgerows and sub-urban land including roads, farmhouses, gardens, etc., ranging from $11 \%$ in PL to $36 \%$ in UK (Fig. 2). All landscapes include water bodies. Surplus water from the IT and NL fields is pumped into channels bordering the area, whereas the boundaries in the other landscapes are defined by small watersheds, into which surplus water from the areas drains, contributing 
to larger river networks (Hansen, 2004; Bienkowski et al., 2009; Molenat et al., 2004).

In the following paragraphs, the biophysical environment and the farming systems of the six landscapes (with longitude, latitude coordinates) are briefly described. However, the exact borders of the landscapes and the farms studied are not given to respect the privacy of the farmers from whom interview data were collected (see Sects. 2.3 and 2.4). Specific land use, livestock, fertiliser and $\mathrm{N}$ input/output data from these interviews and landscape surveys are presented in the results section.

\subsubsection{Turew, $\mathrm{PL}\left(\mathbf{5 2 . 0}^{\circ} \mathrm{N}, \mathbf{1 6 . 8}^{\circ} \mathrm{E}\right)$}

The Turew landscape $\left(22.5 \mathrm{~km}^{2}\right)$ covers the Wyskoć channel catchment, located in the West Polish Lowland. The terrain consists of a rolling plain, made up of a slightly undulating moraine, with many drainage valleys. The elevation ranges from $75 \mathrm{~m}$ in drainage valleys to $90 \mathrm{~m}$ at the highest points. In general, light-textured soils with favourable conditions for infiltration are found in the higher areas. Annual precipitation in this area is $594 \mathrm{~mm}$. Most of the precipitation is concentrated in the spring and summer months $(365 \mathrm{~mm})$. The mean annual air temperature is $8^{\circ} \mathrm{C}$, with large seasonal differences.

The farming systems are dominated by 98 traditional family farms (average area 12.8 ha, typically mixed farming including beef cattle, pigs, poultry and dairy production, and high-value horticultural crops), with manure commonly managed as farmyard manure (Fig. 1). The area also includes three large commercial farms with more modern livestock housing and manure handling techniques (average area 875 ha, two with dairy cows and one with horse breeding, accounting for about $54 \%$ of the total livestock in the area). The arable land use is dominated by rye and triticale cereals (with a relatively low $\mathrm{N}$ application of about $60-160 \mathrm{~kg} \mathrm{~N}$ $\mathrm{ha}^{-1}$, and more heavily fertilised maize, forage, oilseed rape and horticultural crops. In this catchment there are multiple sources of $\mathrm{N}$ emissions with scattered manure storage and livestock buildings, as well as fields and gardens surrounded by extensive forests and hedgerow patches.

\subsubsection{North Friesian Woodlands, NL $\left(53.1^{\circ} \mathrm{N}, 9.1^{\circ} \mathrm{E}\right)$}

The Dutch landscape $(5 \times 5 \mathrm{~km})$ is flat with relatively homogeneous soils dominated by Gleyic Podzols, and lies just above sea level. The groundwater level in the central parts of the landscape is controlled via pumping, at between 25 and $40 \mathrm{~cm}$ below surface, while the average groundwater level in other parts of the area is more than $120 \mathrm{~cm}$ below surface (Sonneveld et al., 2006). The average temperature ranges from $2-4{ }^{\circ} \mathrm{C}$ in winter to $16-20^{\circ} \mathrm{C}$ during summer, with a mean annual precipitation of $763 \mathrm{~mm}$ over the last 30 -year period.
Northern Friesland has for generations been the heartland of dairy farming in the Netherlands (Tress et al., 2006), and the central study site in the NFW landscape is totally dominated by dairy farms, with an average farm size of $50 \mathrm{ha}$, and with more than 1.5 high-yielding dairy cows per ha (annual yield of $7200 \mathrm{~kg}$ milk) and 2.6 other cattle per ha. Seven of these farms are located inside the landscape, and the rest outside. There are no pigs or poultry in the central parts of the landscape, but there are seven small farms with sheep and six with horses inside the area, and outside the central landscape more than $500 \mathrm{~m}$ from the fields of the dairy farms in the study, there were five commercial chicken farms. Within the landscape, high-yield grassland is the most widespread type of agricultural land use, followed by silage maize. Grazing is common, although most of the manure in the landscape is collected in the form of slurry from loose housing systems, and spread to fields during the growing season. In contrast to other agricultural landscapes of the Netherlands, the area is characterised by many hedgerows along ditches and water channels (hence the name, Fig. 1). However, $19 \%$ of nonagricultural land in the area is dominated by sub-urban land use $(11 \%)$ and roads $(5 \%)$, with less than $4 \%$ taken up by woodlands, orchards, water bodies and other semi-natural areas.

\subsubsection{Naizin, $\mathrm{FR}\left(48.0^{\circ} \mathrm{N}, \mathbf{2 . 8}^{\circ} \mathrm{W}\right)$}

The Kervidy-Naizin catchment in Brittany covers an area of $4.9 \mathrm{~km}^{2}$. It is characterised by gentle slopes of less than $5 \%$, with the northern part being particularly flat. The soils are loamy (dominated by luvisols), with well-drained upper slopes and poorly-drained lower slope areas (INRA, 2008). The mean annual precipitation over the last 30 years and mean annual potential evapotranspiration from 1994 to 2004 are 909 and $710 \mathrm{~mm}$, respectively. The maximum and minimum average monthly precipitation occurs in January $(116 \mathrm{~mm})$ and July $(45 \mathrm{~mm})$, respectively (Molenat et al., 2008).

The land use is mainly agriculture, dominated by intensive livestock farming with cattle, pigs and poultry. About $32 \%$ of the agricultural surface area of the catchment is covered by meadows, most of which are grazed intensively by dairy cows or other cattle (Molenat et al., 2004, 2008, Fig. 1). The arable land is dominated by winter wheat and maize crops, with the remainder taken up by leguminous plants, set-aside land and oilseed rape. The soil surface $\mathrm{N}$ surplus in the Naizin catchment was estimated at around $220 \mathrm{~kg} \mathrm{~N}$ $\mathrm{ha}^{-1}$ during the 1990s (Bouraoui et al., 1999), while Durand (2004) calculated the leachable $\mathrm{N}$ at $150 \mathrm{~kg} \mathrm{ha}^{-1}$ for the same period. The non-cultivated area is occupied by roads and housing, with only a few forested patches. 


\subsubsection{Piana del Sele, IT $\left(40.5^{\circ} \mathrm{N}, 14.9^{\circ} \mathrm{E}\right)$}

Located on an alluvial river plain situated on the coast of Southern Italy (Campania Region), the $3 \times 4 \mathrm{~km}$ study landscape is characterised by a typical Mediterranean climate with hot and dry summers and cool, rainy winters. The mean annual precipitation and temperature are $900 \mathrm{~mm}$ and $15.5^{\circ} \mathrm{C}$, respectively. The soils are generally coarse-loamy, but with large variations including fine-loamy, fine-silty and coarse-silty soils. In the lower-lying part of the landscape, drainage water is pumped and channelled to the sea. Many areas are occasionally flooded during winter, especially in the large areas covered by plastic tunnels for vegetable production, where the soil absorption of rainfall is impeded.

The landscape is characterised by highly productive farming systems. Vegetables with multiple annual crop cycles cover more than $80 \%$ of the agricultural area harvested, with a fifth of the area under plastic cover, and a few cereal fields $(<2 \%$ of the agricultural area). The remaining area belongs to two very intensive water buffalo dairy farms (for mozzarella cheese production), with livestock houses, muddy paddocks (Fig. 1) and fodder crop areas (primarily alfalfa and silage maize). The area features high $\mathrm{N}$ emissions from mineral and organic fertilisers, silage fodders, and other livestock-related activities, and it is one of the strongest $\mathrm{N}$ and greenhouse gas emitting agricultural areas in Southern Italy, representing irrigated, high-input and high-income agriculture under Mediterranean conditions. The coastalforested area accounts for about $15 \%$ of the total landscape area, and is the other main land use type apart from agriculture.

\subsubsection{Southern Scotland, UK $\left(56^{\circ} \mathrm{N}, 3^{\circ} \mathrm{W}\right.$; approximate location to protect farm anonymity)}

The northernmost study landscape $(6 \times 6 \mathrm{~km})$ includes two similar-sized catchments, one dominated by moorlands and peaty soils, the other containing a variety of agricultural and other land uses on mixed soils including brown forest soils, peaty alluvial soils, peaty podzols and non-calcareous gley soils. The annual average temperature is $8^{\circ} \mathrm{C}$, and with a mean annual precipitation of $1040 \mathrm{~mm}$ the water surplus is considerable.

The agricultural activities are mostly related to extensive beef and sheep farming and a number of poultry sheds housing laying hens (incl. free-range systems). The northwestern part is dominated by semi-natural moorland, whereas the southeastern part is mainly agricultural land. Within the wider landscape, the contrasting catchments are characterised by (a) peat bog with very low density sheep grazing (Fig. 1), and (b) agricultural land consisting of mainly grazed grassland at different stocking densities, with small areas of fodder crops and two major poultry farms, the largest of these without land and with all manures exported from the landscape. In the Scottish landscape, grasslands included both improved pastures $(48 \%)$ and rough grassland with some grazing (14\%), and the $36 \%$ of other land uses included moorland that is grazed at very low stocking densities $(13 \%$ of the area).

\subsubsection{Bjerringbro, $\mathrm{DK}\left(56.3^{\circ} \mathrm{N}, 9^{\circ} 7^{\circ} \mathrm{E}\right)$}

The Danish study landscape is centred around the 843 ha upper catchment of the small stream Tyrebækken, which runs into the river Gudenå approximately $3 \mathrm{~km}$ downstream of the study area (Wohlfart et al., 2012), south of the town Bjerringbro. The soils are sandy-loamy on a relatively flat and fertile moraine plateau covering most of the area, but with more sandy soils on the lower-lying river terraces, and narrow areas of organic soils along the stream (Dalgaard et al., 2002b). The elevation ranges from 25 to $58 \mathrm{~m}$ above sea level, with a mean annual temperature of $7.7^{\circ} \mathrm{C}$ and an annual precipitation of $712 \mathrm{~mm}$. The mean temperatures of the coldest and warmest months of the year (February and July) are $0.1{ }^{\circ} \mathrm{C}$ and $15.4{ }^{\circ} \mathrm{C}$, respectively (PlanteInfo, 2012).

Specialised farms with pig, dairy and cereal cash crop production dominate the farming systems of the landscape, supplemented by smaller hobby and part-time farms, typically with a more extensive crop and beef cattle production. $\mathrm{N}$-efficient, slurry-based manure handling systems are implemented on most farms (Fig. 1), with an obligatory 24month storage capacity, and the potential to spread all manure during the growing season when high N-efficiency can be obtained (Kronvang et al., 2008). Cereals and oilseed rape are typically grown on the moraine plateau, with permanent grasslands along the stream and on steeper slopes, but highyield rotational grass/clover and maize silage fodder crops also grown on the best moraine soils, with significant $\mathrm{N}$ input from both synthetic fertilisers, manure and clover $\mathrm{N}$-fixation (Dalgaard et al., 2002a; Hutchings et al., 2004). It is a landscape with mixed land use, including significant patches of woodlands, bogs, permanent set-aside, hedgerows, gardens and other urbanized land use.

\subsection{Farm $\mathrm{N}$ balance and surplus}

For the synthesis of results on agricultural $\mathrm{N}$ balances in the landscapes studied, the farm $\mathrm{N}$ balance was defined as from the farm gate (Dalgaard et al., 1998), including $\mathrm{N}$ inputs (i) to the farm, and $\mathrm{N}$ outputs (o) from the farm (Fig. 3).

Based on the farm data collection described in Sect. 2.3, the $\mathrm{N}$ surplus was, for all individual farms, calculated from Eq. (1) as the difference between net $\mathrm{N}$ output from the farm in the form of milk (o1) and other animal produce (incl. meat, live animals, eggs and wool), and the net $\mathrm{N}$ input to the farm in the form of net fodder import, net fertiliser import and $\mathrm{N}$ from the atmosphere. The net export of other animal produce was calculated as $\mathrm{N}$ in the produce exported (o2) minus $\mathrm{N}$ in imported livestock (i5), (in the present study, $\mathrm{N}$ in eggs and wool was only relevant for a few farms in some of the 

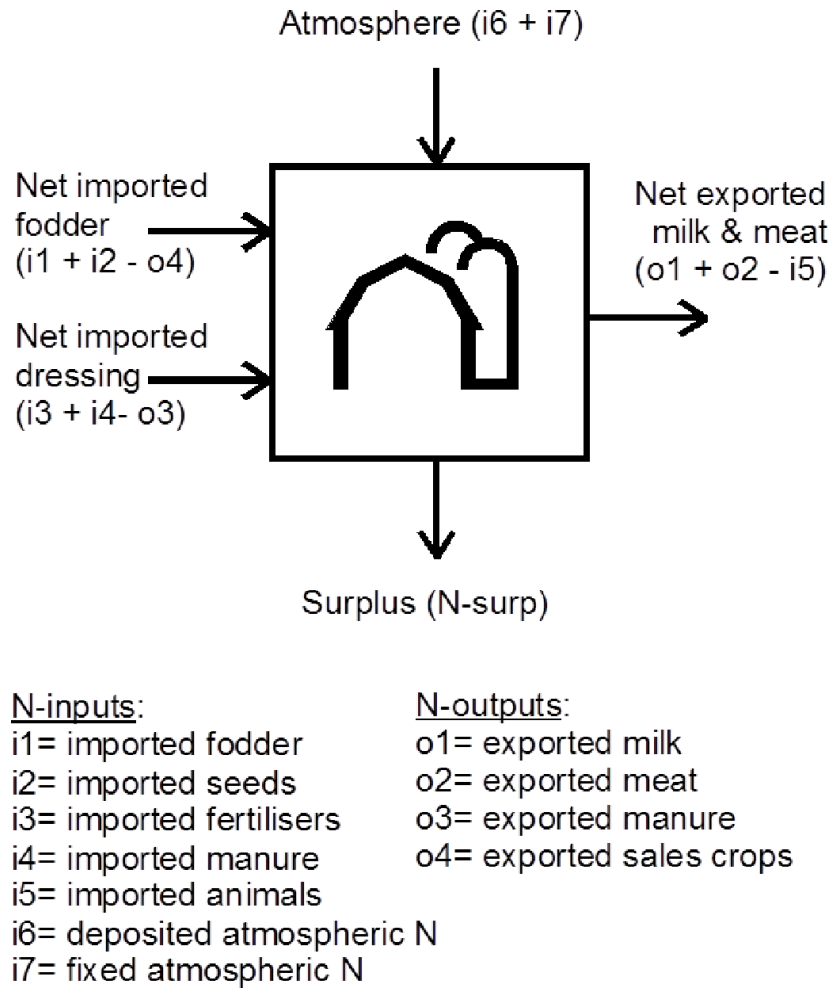

Fig. 3. Farm $\mathrm{N}$-inputs (i1-i7), N-outputs (o1-o4) and surplus (Nsurp) (from Dalgaard et al., 1998). The same balance can be calculated for a number of farms within a landscape. In this context "exported meat" (o2) also includes $\mathrm{N}$ in the form of live animals, eggs and wool sold, and the term "dressing" is used as the sum of synthetic fertilisers and animal manures.

landscapes, and $\mathrm{o} 2$ therefore primarily covers meat export). The net fodder import was calculated as the sum of $\mathrm{N}$ in imported fodder (i1) and seed (i2), minus $\mathrm{N}$ in cash crops sold (o4). Net imported straw is also included here. If a particular farm sold more $\mathrm{N}$ in cash crops than it imported in the form of fodder, straw and seeds, the net fodder import was negative. Similarly, the net fertiliser import was calculated as the sum of $\mathrm{N}$ in imported synthetic fertiliser (i3) and manure (i4) minus $\mathrm{N}$ in exported manure (o3), where the term "dressing" in Fig. 3 covers the sum of synthetic fertilisers and animal manures. Finally, $\mathrm{N}$ from the atmosphere is defined as the sum of the atmospheric $\mathrm{N}$ deposition (i6) and $\mathrm{N}$ fixed by legumes (Leguminosae sp.) (i7). Here, the $\mathrm{N}$ deposition for each farm was obtained from EMEP $(2008,2010)$ as the average modelled total annual dry and wet $\mathrm{N}$ deposition in the EMEP grid square containing the respective landscape centre coordinate for 2006 and 2008 (annually $11.2 \mathrm{~kg} \mathrm{~N} \mathrm{ha}^{-1}$ for PL, $16.9 \mathrm{~kg} \mathrm{~N} \mathrm{ha}^{-1}$ for NL, $17.4 \mathrm{~kg} \mathrm{~N} \mathrm{ha}^{-1}$ for FR, $8.4 \mathrm{~kg}$ $\mathrm{N} \mathrm{ha}{ }^{-1}$ for IT, $8.1 \mathrm{~kg} \mathrm{~N}^{-1}$ for UK and $11.8 \mathrm{~kg} \mathrm{~N}^{-1}$ for DK). These actual values are probably higher in the landscapes with intensive livestock farming (Durand et al., 2010), an issue that is included in the sensitivity analysis section of the discussion of farm inventory method (Sect. 4). Based on
Høgh-Jensen and Schjørring (1994) and Heij and Erisman (1997), i7 was simply estimated at $100 \mathrm{~kg} \mathrm{~N} \mathrm{ha}^{-1} \mathrm{yr}^{-1}$ for field peas, lupines and faba beans, $150 \mathrm{~kg} \mathrm{~N} \mathrm{ha}^{-1} \mathrm{yr}^{-1}$ for alfalfa and grass/clover ley fields with more than $25 \%$ clover, and $20 \mathrm{~kg} \mathrm{~N} \mathrm{ha}^{-1} \mathrm{yr}^{-1}$ for other grass/clover fields with a lower clover content. This is discussed in Sect. 4.

$\mathrm{N}$-surplus $=\mathrm{i} 1+\mathrm{i} 2+\mathrm{i} 3+\mathrm{i} 4+\mathrm{i} 5+\mathrm{i} 6+\mathrm{i} 7-\mathrm{o} 1-\mathrm{o} 2-\mathrm{o} 3-\mathrm{o} 4$

$\mathrm{N}$-surplus ( $\mathrm{kg} \mathrm{N} \mathrm{ha}^{-1} \mathrm{yr}^{-1}$ ) thus summarises $\mathrm{N}$ lost from the farm (in the form of emissions to the atmosphere or leaching to the soil-water system) or accumulated in the farming system (in stores, soils, perennial crops, etc.) during a particular year. In addition, the N-efficiency is defined from the values of Fig. 3 as net $\mathrm{N}$ output in products sold, divided by net $\mathrm{N}$ inputs purchased by the farmer:

$\mathrm{N}$-efficiency $=\left([\mathrm{o} 1+\mathrm{o} 2-\mathrm{i} 5] \times([\mathrm{i} 1+\mathrm{i} 2-\mathrm{o} 4]+[\mathrm{i} 3+\mathrm{i} 4-\mathrm{o} 3])^{-1}\right.$

The farm N-surplus, and the split between the $\mathrm{N}$-input and $\mathrm{N}$ output categories of Fig. 3, are summarised for all farms in each of the landscapes studied, and $95 \%$ confidence intervals (based on standard deviations) caused by differences in the farms within the landscape areas are included. This allows a comparison of the overall $\mathrm{N}$ balance in the landscapes and provides the background for a discussion of differences in the characteristics of farming landscapes and the potential for $\mathrm{N}$ mitigation.

\subsection{Farm data collection}

At the start of the project, a common template for the collection of farm data from the six study landscapes was prepared, together with questionnaires to be used when interviewing farmers in the landscapes (Drouet et al., 2011; Dragosits et al., 2011). Data were organised in a relational database and included general farm data and related information about management of individual fields (Hutchings et al., 2012), manure stores and livestock houses (Dragosits and Dalgaard, 2008; Happe et al., 2011). The aim was to interview all farmers with fields in the defined landscapes. This was generally successful, except in the Dutch landscape, where less than $30 \%$ of the farm area was covered by interviews, and half of the farms included for NL were actually placed outside the landscape. However, animal counts were available for all NL farms, and since the farms of that area were all relatively similar dairy farms, this was not considered a serious problem. Moreover, a preliminary comparison of $\mathrm{N}$ surpluses from the group of farms inside and outside the NL study landscape, respectively, did not show significant differences. In the other landscapes, the inventories covered over $90 \%$ of the farmland, with very few farms not included, either because the farmer did not want to participate (in total less than 
10 farms), the quality of the data collected was considered poor, or most of the farm was located outside the landscape.

The results of the present study mostly rely on the general farm data collected, including the following:

- Types and numbers of animals on the farm at the start of the calendar year and arrived or left during the year

- Types and quantities of manures on the farm at the start of the calendar year and produced, imported or exported during the year

- All other main N-containing materials and produce generated on the farm, imported or exported during the year

- Stores of all other main N-containing materials on the farm at the beginning and by the end of the year.

In addition, for most of the farms, data on field areas, crop types, the proportion of the time the fields were grazed, and the consumption of synthetic and organic fertilisers were collected for each field (except for NL, where only general farm data with aggregated figures for each farm were included in the database). All data were collected for one calendar year, except for field operations associated with winter cropping, which were collected for the cropping year. For example, fertiliser applied in the previous autumn to the crop harvested in the calendar year was included, whereas the field operations after harvest were excluded (e.g., the fertiliser distributed after the last harvest date was not included, because it was considered as preparation for the following year's crop). In PL, FR, UK and DK the farm interviews were carried out for the year 2008, whereas data from NL relied on data for 2007, and for logistical reasons data for IT were collected for 2009.

A total of 222 farms were included in the study, with a total farm area of 11440 ha, covering almost all farms included by local partners in the common database. The data are therefore considered representative for the study landscapes, except perhaps for IT, where one of the two large water buffalo farms was not included. Moreover, for UK the large landless poultry farming was deliberately treated separately in the N-balance calculations; partly because the collected data on livestock numbers and manure export from this farming system was uncertain, and partly to avoid division by zero when the individual farm $\mathrm{N}$ surplus values were summarised per farm area (see also discussion). Finally, for FR and UK three farms declined to participate. However, as elaborated in the discussions section, this was considered not to have significant consequences for the overall results.

\subsection{Templates and default values for N-containing ma- terials and products}

For the farm data collection, template lists with all main Ncontaining materials and products were made, including livestock types, crop types, manure types, and other imported
Table 1. Default N contents of imported and exported materials.

\begin{tabular}{|c|c|}
\hline Material & $\begin{array}{r}\text { Default } \mathrm{N} \text { content } \\
\left(\mathrm{kg} \mathrm{N} \mathrm{Mg}^{-1}\right. \\
\text { fresh weight })\end{array}$ \\
\hline beet pulp (dried) & 14.4 \\
\hline cereals & 16.3 \\
\hline eggs & 18.1 \\
\hline feed milk & 56.3 \\
\hline fertiliser nitrogen & 1000.0 \\
\hline fresh milk & 5.0 \\
\hline fresh green forage (alfalfa) & 6.0 \\
\hline fresh green forage (grass) & 6.3 \\
\hline fresh green forage (grass/clover) & 5.7 \\
\hline full-ration concentrate mix & 25.6 \\
\hline hay & 16.0 \\
\hline high energy concentrate & 52.2 \\
\hline low energy concentrate & 25.8 \\
\hline medium energy concentrate & 43.9 \\
\hline meat (live animals) & 46.0 \\
\hline rape cake & 49.3 \\
\hline silage (alfalfa) & 18.0 \\
\hline silage (beet pulp) & 3.8 \\
\hline silage (clover grass) & 9.1 \\
\hline silage (grass) & 8.5 \\
\hline silage (maize) & 3.9 \\
\hline silage (whole crop) & 6.0 \\
\hline soy beans & 56.4 \\
\hline soybean oil cake & 70.2 \\
\hline straw & 5.4 \\
\hline sugar beets & 2.1 \\
\hline wet distillery grain & 3.4 \\
\hline whey & 35.0 \\
\hline whole crop fresh & 5.8 \\
\hline wool & 3.0 \\
\hline
\end{tabular}

and exported farm inputs and outputs. In an iterative process, an initial draft list was sent to the local partners and revised to include all major types present in the landscapes (Dragosits et al., 2011). Additionally, a default N content for each type was proposed based on figures from Dalgaard et al. (1998, 2002a) and Strudsholm et al. (1997), with the possibility for local adaption by each of the landscapes. Tables 1 and 2 show the default $\mathrm{N}$ contents for imported and exported materials and types of manure, respectively. In general, the local revisions to these standard values were few and minor and are not shown here. In addition to the general values, more specific default values for subtypes were included in the database and used by the partners. This included default $\mathrm{N}$ contents for specific types of crops; e.g., a specific default value of $14.96 \mathrm{~kg} \mathrm{~N} \mathrm{Mg}^{-1}$ for grain of winter rye cereals $(\mathrm{Se}-$ cale cereale), $18.79 \mathrm{~kg} \mathrm{~N} \mathrm{Mg}^{-1}$ for winter wheat (Triticum aestivum), $31.45 \mathrm{~kg} \mathrm{~N} \mathrm{Mg}^{-1}$ for oilseed rape (Brassica napus), $48.71 \mathrm{~N} \mathrm{Mg}^{-1}$ for faba beans (Vicia faba), and specific 
Table 2. Default $\mathrm{N}$ contents in imported and exported manure.

\begin{tabular}{lr}
\hline Manure type & $\begin{array}{r}\text { Default N content } \\
\left(\mathrm{kg} \mathrm{N} \mathrm{Mg}^{-1}\right)\end{array}$ \\
\hline cattle farm yard manure (FYM) & 8.4 \\
composted manure/compost from other materials & 2.0 \\
degassed cattle slurry & 3.9 \\
degassed pig/mixed slurry & 4.0 \\
horse FYM & 7.5 \\
liquid fraction of cattle manure & 5.4 \\
liquid fraction of mixed manure & 5.0 \\
liquid fraction of pig manure & 4.0 \\
mixed FYM & 8.6 \\
mixed slurry & 5.4 \\
other organic fertiliser (e.g., bone meal) & 2.0 \\
pig FYM & 8.8 \\
pig slurry (sows and piglets) & 4.6 \\
pig slurry (fattening pigs) & 5.4 \\
sewage sludge & 6.0 \\
sheep/goat FYM & 8.4 \\
solid fraction of cattle manure & 5.6 \\
solid fraction of pig (fatteners) or mixed manure & 5.9 \\
solid fraction of pig manure (sows + piglets) & 8.1 \\
solid poultry manure & 21.0 \\
\hline
\end{tabular}

$\mathrm{N}$ contents for the different types of synthetic $\mathrm{N}$ fertilisers used in the landscapes.

\subsection{Verification measurements}

In addition to the farm data collection, measurements were made of various $\mathrm{N}$ compounds in the air, soil and water within the landscapes during the period 2008-2009 (Theobald et al., 2011) in order to assess the fate of the $\mathrm{N}$ surplus produced by the farms. Measurements of mean monthly ammonia $\left(\mathrm{NH}_{3}\right)$ concentrations were made at up to 31 locations within each of the six study landscapes. Soil nitrate concentrations in the top $20 \mathrm{~cm}$ soil layer were measured periodically (up to 18 times per year) at up to nine locations within four of the study landscapes (DK, FR, IT and PL). Nitrate concentrations were also measured periodically (up to 12 times per year) in the groundwater at up to 15 locations within three of the landscapes (DK, FR, and PL) and in stream water at up to nine locations within five of the landscapes (all except IT). See also Schelde et al. (2012) and Wohlfart et al. (2012) for more information about the monitoring designs, and Ullrich and Volk (2010) and Bende-Michl et al. (2011) for a further discussion of sampling strategies and treatment of the variability in results, or Vogt et al. (2012) for a detailed investigation of $\mathrm{N}$ budgets derived from measurements and modelling in the UK landscape.

\section{Results}

This section summarises results from the farm data collection (Sect. 3.1), the derived $\mathrm{N}$ balances for the six study landscapes (Sect. 3.2), comparison with independent measure-
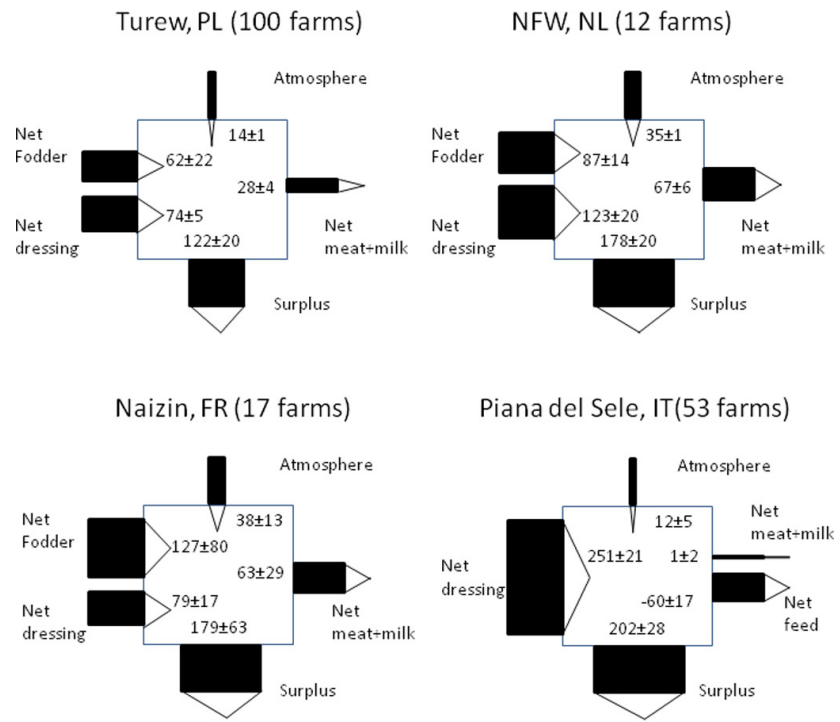

Piana del Sele, IT(53 farms)

South Scotland, UK (25 farms*)
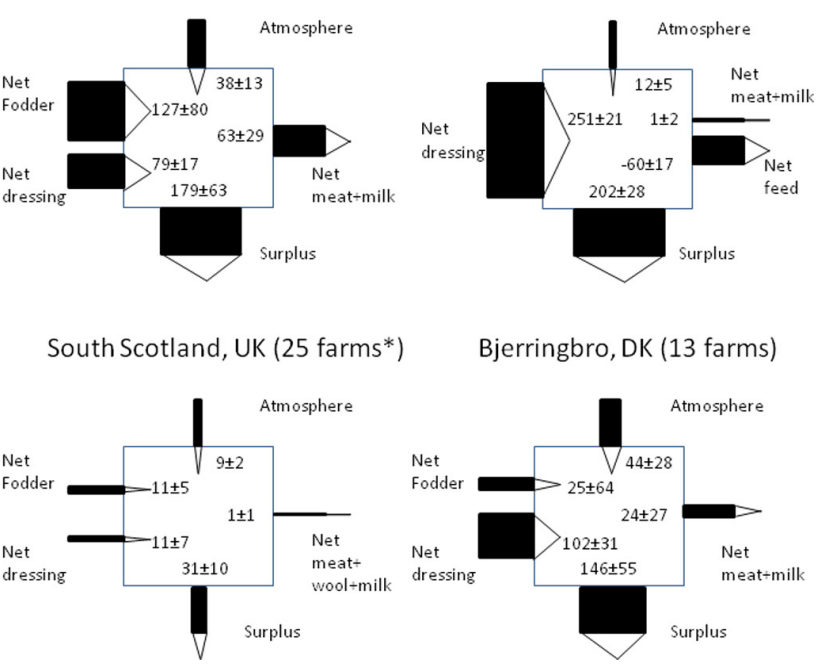

Fig. 4. $\mathrm{N}$ surpluses $\left(\mathrm{kg} \mathrm{N} \mathrm{ha}^{-1} \mathrm{yr}^{-1}\right)$ for each of the six landscapes, partitioned into the Fig. 3 components of the $\mathrm{N}$ balance, including $\mathrm{N}$ fixed or deposited from the atmosphere, net $\mathrm{N}$ fodder import (or feed export if negative), net import of dressing in the form of fertilisers or manure, and the net export of milk and meat, also including $\mathrm{N}$ in eggs and wool (all with $95 \%$ confidence intervals under the assumption of a normal distribution). (*) excluding landless poultry farming in Scotland. If the landless poultry farming was included, the UK N-surplus would be similar to PL and DK, but with a much larger fodder import of around $300-400 \mathrm{~kg} \mathrm{~N}^{-1} \mathrm{yr}^{-1}$, a net manure export of around $150-200 \mathrm{~kg} \mathrm{~N} \mathrm{ha}^{-1} \mathrm{yr}^{-1}$ and a net export of eggs, meat, wool and milk of around $120 \mathrm{~kg} \mathrm{~N} \mathrm{ha}^{-1} \mathrm{yr}^{-1}$.

ment data of $\mathrm{N}$ in air and soils (Sect. 3.3), and analysis of the $\mathrm{N}$-surplus variation and hotspots (Sect. 3.4). A special case study on the effect on $\mathrm{N}$-mitigation measures was carried out in the Danish study landscape, with the N-surplus results for 2008 compared to a previous study from the period 19941998 (Sect. 3.5).

\subsection{Farm data}

The number of farms studied, and the farm areas covered, varied between landscapes, with the largest number of farms in Poland and the smallest sample from the Netherlands (Table 3). Fortunately, the most homogeneous farm size and farm type distribution was also found in the landscapes with the smallest number of samples, where the differences 

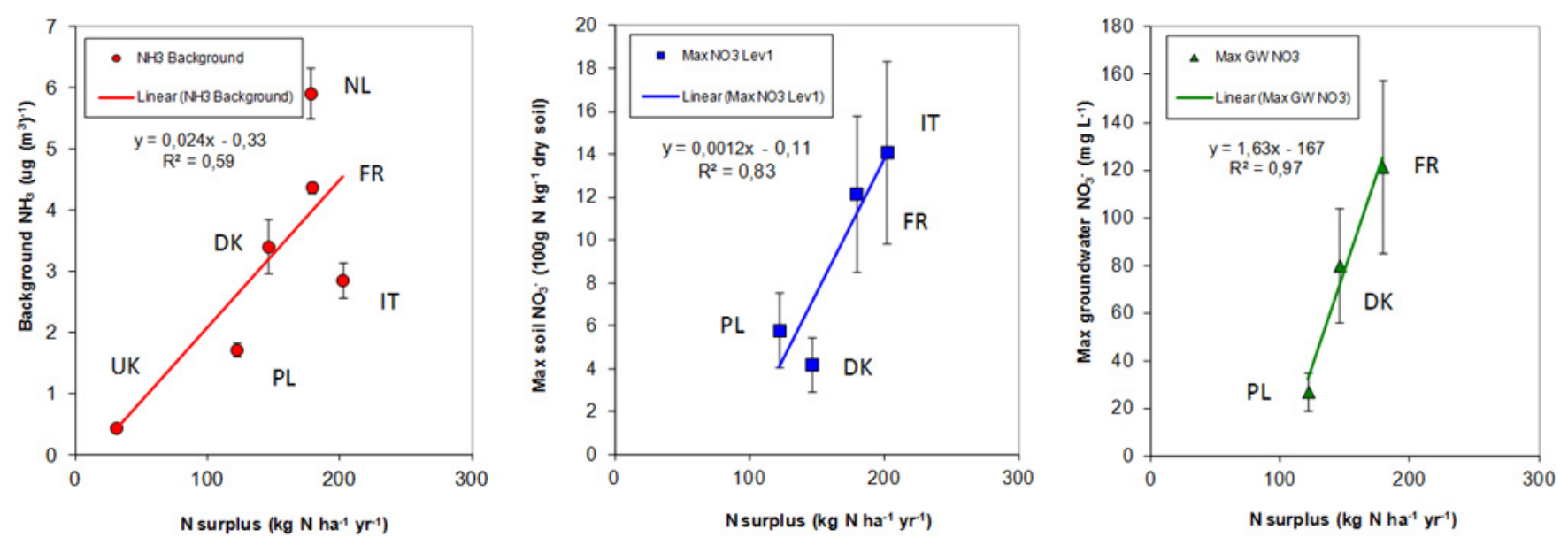

Fig. 5. Comparison of average landscape $\mathrm{N}$ surpluses with measured ammonia concentrations (lowest site-mean, left) and soil nitrate levels (maximum nitrate concentration measured in the A-horizon of any site, centre) and groundwater nitrate levels (maximum nitrate concentration measured at any site, right). Measurement uncertainty for ammonia was calculated from the standard errors of the individual monthly concentrations and for nitrate from the mean uncertainty for the concentration values where uncertainty was reported ( $\pm 30 \%$ for both soil and groundwater).

between the average and the median farm size in NL, DK and FR were $6 \%, 31 \%$ and $51 \%$, respectively, compared to much larger differences in the landscapes of IT, PL and UK. This is because the latter three landscapes are characterised by many small farms and a few very large farms, with median farm sizes of $5 \mathrm{ha}, 11$ ha and 42 ha for IF, PL and UK, respectively, compared to an average farm size of 19 ha, 47 ha and 193 ha for NL, DK and FR, respectively.

The results of the farm interviews confirmed the general patterns observed during the initial characterisation of the landscapes, with the most mixed livestock production in PL and FR, specialised dairy production in NL and IT, and meat production from pigs, poultry, beef or sheep dominating in DK and UK (Table 3, Sect. 2.1). In general, the crops grown in the landscapes correspond to the needs of the livestock being raised in the individual landscapes, with grasslands and forage crops for ruminants (cattle and sheep) and cereals for non-ruminants (pigs and poultry). An exception to this pattern is the landless poultry production in UK and the intensive water buffalo dairy production in IT, which were both based on imports of feedstuff decoupled from the local crop land use. In addition, these two systems export almost all of their manure out of the landscape. Nevertheless, even if these systems were included in the $\mathrm{N}$ surplus calculations, the livestock densities in these two landscapes are relatively low, compared to the other landscapes, especially NL and FR, and have a more heterogeneous distribution between farms. Finally, the use of synthetic fertiliser was much higher in IT than in the other landscapes due to the intensive production of outdoor and plastic-covered vegetables, with up to four crops per year, and the associated high fertilisation rate.

\subsection{Landscape nitrogen balances}

The farm $\mathrm{N}$ surpluses and the components of the $\mathrm{N}$ balance described in Fig. 3 were calculated and compared for the six landscapes (Fig. 4). The highest $\mathrm{N}$ surpluses, in descending order, were found in the landscapes of IT, FR, NL and DK, but with no statistically significant differences between the $\mathrm{N}$ surpluses in these four landscapes. However, the $\mathrm{N}$ surplus in PL was significantly lower than in both NL and FR, and the N surplus from the land-based farming in UK was significantly lower than from any of the other landscapes. If the landless poultry farming was included, the Scottish landscape would have a $\mathrm{N}$ surplus similar to those of PL and DK.

As expected, the highest $\mathrm{N}$ export of products in the form of meat and milk (NL and FR) or feed and vegetables for human consumption (IT) was found in areas with the highest net $\mathrm{N}$ inputs of fodder (FR and NL), atmospheric $\mathrm{N}$ input (DK, FR and NL), and imports of fertiliser and manure dressings (IT and NL), whereas the lower N-input systems of PL and UK also showed significantly lower net $\mathrm{N}$ outputs, and as mentioned a subsequently lower $\mathrm{N}$ surplus.

\subsection{Comparison with independent $\mathrm{N}$ measurements}

In order to investigate links between farm $\mathrm{N}$ surplus and $\mathrm{N}$ losses to the environment, correlations between the concentrations of $\mathrm{N}$ compounds measured within the six landscapes and the average landscape $\mathrm{N}$ surpluses were calculated (Fig. 5). A significant linear relationship $\left(R^{2}=0.59\right)$ was found between the lowest site-mean atmospheric $\mathrm{NH}_{3}$ concentration for each landscape and the respective $\mathrm{N}$ surplus (Fig. 5, left). The lowest site-mean is indicative of the emission density of the landscape and surrounding areas. 
Table 3. Agricultural land use and livestock production characteristics of the study landscapes.

\begin{tabular}{|c|c|c|c|c|c|c|c|}
\hline Landscape & $\begin{array}{l}\text { Turew, } \\
\text { PL }\end{array}$ & $\begin{array}{r}\text { NFW, } \\
\text { NL }\end{array}$ & $\begin{array}{r}\text { Naizin, } \\
\text { FR }\end{array}$ & $\begin{array}{r}\text { Piana del Sele, } \\
\text { IT }\end{array}$ & $\begin{array}{r}\text { Southern Scotland, } \\
\text { UK }\end{array}$ & $\begin{array}{r}\text { Bjerringbro, } \\
\text { DK }\end{array}$ & Total \\
\hline Farms studied (number) & 100 & 12 & 17 & 53 & 27 & 13 & 222 \\
\hline Farm area $($ ha) & 4556 & 658 & 1246 & 931 & 3092 & 957 & 11440 \\
\hline \multicolumn{8}{|l|}{ Crops ( $\%$ of farm area): } \\
\hline Alfalfa & 3.5 & & & 8.1 & & & 2.1 \\
\hline Covered orchards & & & & 0.7 & & & 0.1 \\
\hline Covered vegetables & & & 1.0 & 15.7 & & & 1.4 \\
\hline Set-aside grassland & & & & & & 0.6 & 0.1 \\
\hline Fava bean & & & 0.7 & & & & 0.1 \\
\hline First yr grass ley & 0.5 & & & & 0.8 & 14.8 & 1.7 \\
\hline First yr grass/clover ley & 0.0 & & & 2.1 & 0.3 & 1.7 & 0.4 \\
\hline Fodder beet & 0.2 & & & & 0.7 & 0.4 & 0.3 \\
\hline Other grass/clover & 0.0 & 88.9 & 10.6 & & 1.6 & 5.9 & 7.0 \\
\hline Maize (silage) & 10.5 & 11.1 & 23.5 & 2.4 & & 2.0 & 7.5 \\
\hline Oats & 2.3 & & 1.1 & & & 3.2 & 1.3 \\
\hline Orchards & 0.4 & & & 1.5 & & & 0.3 \\
\hline Outdoor vegetables & 0.5 & & & 67.8 & & & 5.8 \\
\hline Peas & & & 2.6 & & & & 0.2 \\
\hline Permanent grass & 15.0 & & 8.9 & & 24.9 & 1.4 & 13.9 \\
\hline Permanent grass ley & & & 13.1 & & 18.5 & 1.7 & 6.5 \\
\hline Potatoes & 0.8 & & 6.4 & & 0.0 & 0.3 & 0.9 \\
\hline Rough/extensive grassland & 1.0 & & 0.3 & & 49.7 & & 14.2 \\
\hline Rye & 11.7 & & & & & & 4.8 \\
\hline Second year grass ley & & & 0.1 & & 0.9 & 1.5 & 0.4 \\
\hline Spring barley & 5.4 & & & & 2.1 & 3.6 & 3.1 \\
\hline Spring rape & 0.1 & & & & 0.2 & & 0.1 \\
\hline Spring wheat & 0.9 & & & & & & 0.4 \\
\hline Sugar beet & 3.5 & & & & & & 1.4 \\
\hline Triticale & 26.4 & & & 1.3 & & 6.0 & 11.4 \\
\hline Winter barley & 0.8 & & 3.7 & & & 15.2 & 2.0 \\
\hline Winter rape & 7.8 & & 1.5 & & & 10.0 & 4.2 \\
\hline Winter wheat & 8.6 & & 26.5 & 0.4 & 0.2 & 31.6 & 8.7 \\
\hline \multicolumn{8}{|l|}{ Livestock (number): } \\
\hline Dairy cows/buffalos & 1233 & 1010 & 477 & 667 & & 60 & 3447 \\
\hline Other cattle/buffalos & 1426 & 1735 & 1466 & 209 & 1049 & 215 & 6100 \\
\hline Sows & 729 & & 1105 & & & 217 & 2051 \\
\hline Piglets & 2968 & & 10250 & & & 2079 & 15297 \\
\hline Pig Finishers & 2092 & & 7714 & & & 4125 & 13931 \\
\hline Poultry & 536 & & 40500 & & 1419692 & & 1460728 \\
\hline Sheep and lambs & & & & & 9338 & & 9338 \\
\hline Horses and ponies & 301 & & & & 50 & & 351 \\
\hline Livestock density $^{\mathrm{a}}\left(\mathrm{LSU} \mathrm{ha}^{-1}\right)$ & 0.7 & 2.9 & 2.5 & 1.0 & $0.3+1.8^{\mathrm{b}}$ & 0.9 & 0.9 \\
\hline Free-range grazing ( $\%$ manure) & 2 & 8 & 19 & 9 & 25 & 16 & 12 \\
\hline Synthetic fertilisers $\left(\mathrm{kg} \mathrm{N} \mathrm{ha}^{-1}\right)$ & 112 & 112 & 79 & 251 & 18 & 80 & 91 \\
\hline
\end{tabular}

This correlation was very much determined by the low value for UK. By contrast, no significant correlation was found between maximum $\mathrm{NH}_{3}$ concentrations and $\mathrm{N}$ surpluses because the maximum values measured within a particu- lar landscape depended on the proximity of the measurement equipment to individual emission sources in the landscape (data not shown). Other significant correlations between the measurements and farm $\mathrm{N}$ surpluses were found 


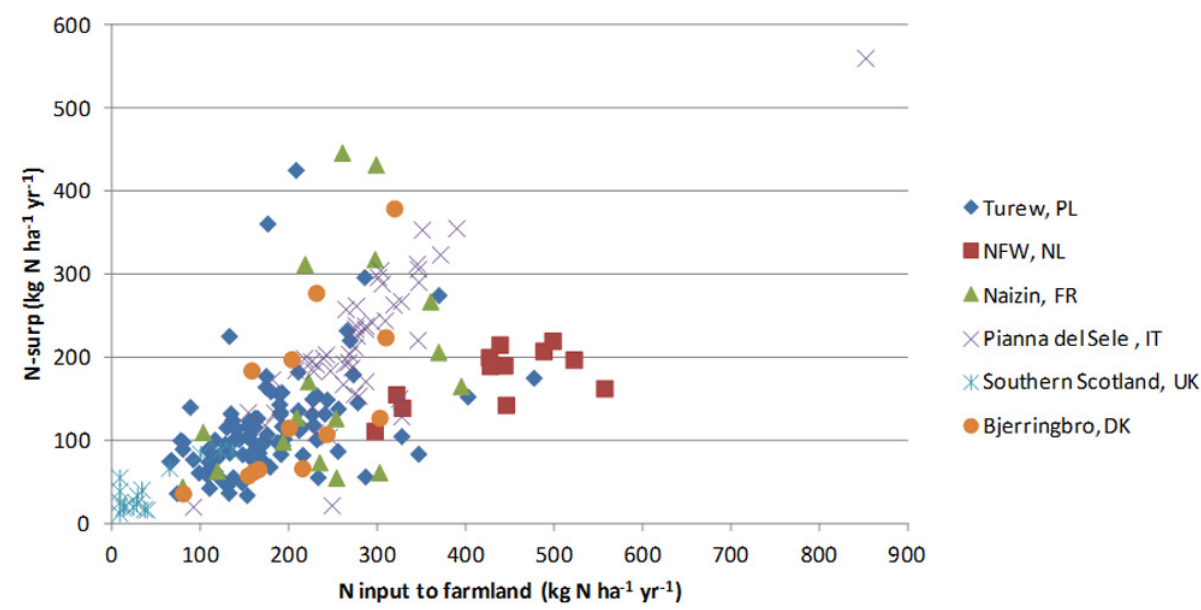

Fig. 6. Calculated farm $\mathrm{N}$ surplus ( $\mathrm{N}$-surp) as a linear function of $\mathrm{N}$ input to farmland, estimated as the average input per field area (total $\mathrm{N}$ input to each farm from fertilisers, manures, $\mathrm{N}$-fixation and deposition from the atmosphere). The landless Scottish poultry farms are excluded.

for maximum soil and groundwater nitrate concentrations ( $R^{2}=0.83$ and 0.97 , respectively) (Fig. 5 centre and right). By contrast, no significant correlations were found between stream-water nitrate concentrations and farm $\mathrm{N}$ surplus. This reflects the short-term nature of the study and the poor direct connectivity between the fields and streams within the landscapes; additional, more long-term studies of relationships with the local hydrology, soils, weather, etc. would be required before conclusions can be drawn (Bende-Michl et al., 2011; Ullrich and Volk, 2010; Vogt et al., 2012). These general results show relatively clear correlations between $\mathrm{N}$ surpluses and $\mathrm{N}$ concentrations in the surrounding environment, and thereby for example potential losses to the atmosphere (e.g., through $\mathrm{NH}_{3}$ emissions) and to the soil and water (indicated by soil and groundwater nitrate measurements). Thus, these results will serve as background material for the further discussion and analyses of the regional variations and potentials for $\mathrm{N}$ pollution mitigation options.

\subsection{N-surplus variation and hotspot farms}

To explore the N-surplus variation (indicated by the confidence intervals of Fig. 4), and to identify and discuss specific $\mathrm{N}$-surplus hotspots and potential $\mathrm{N}$-mitigation measures in the six landscapes, the farm $\mathrm{N}$-surplus values were plotted against the average farmland $\mathrm{N}$ input in the form of synthetic fertilisers, manures, $\mathrm{N}$ fixation and deposition from the atmosphere (Fig. 6). A statistically significant $\left(R^{2}=0.31\right)$, but not very clear, positive linear correlation between land-based $\mathrm{N}$ input and the derived per area $\mathrm{N}$-surpluses was found, and with interesting differences between the hotspot farms in each of the six landscapes.

Both the highest average $\mathrm{N}$-surplus and some of the largest hotspots were found in IT, which contains the largest proportion of farms above the linear regression line of Fig. 6 . The largest single hotspot was the water buffalo farm (furthest to the right in Fig. 6), but the intensive vegetable production sites also showed significantly higher $\mathrm{N}$ surpluses than the average. This was in sharp contrast to the two roughage fodder arable farms of IT, which had the lowest $\mathrm{N}$-surplus values (about $22 \mathrm{~kg} \mathrm{~N} \mathrm{ha}^{-1} \mathrm{yr}^{-1}$ ) despite relatively high $\mathrm{N}$ inputs of 91 and $248 \mathrm{~kg} \mathrm{~N} \mathrm{ha}^{-1} \mathrm{yr}^{-1}$, respectively. However, this was due to a large export of high $\mathrm{N}$-content alfalfa and maize silage to the main farm section where animals were bred, and therefore in reality these farms were closely coupled to the water buffalo milk production and were therefore not really examples of an independent farming system with a low $\mathrm{N}$ surplus.

The other major hotspot farms were in FR, PL and DK. The farms with the largest $\mathrm{N}$-surplus in DK were all hobbybased beef cattle farms with a large proportion of $\mathrm{N}$-fixing grass/clover crops, significant feed imports and no export of plant products, whereas the major hotspots in FR and PL were pig farms. This was in contrast to some of the other pig farms in these landscapes, and especially to the two industrial pig farms in DK, which were both (despite relatively large land-based inputs) examples of farms with very low $\mathrm{N}$ surpluses compared to the average (the two points with an $\mathrm{N}$ input of 199 and $302 \mathrm{~kg} \mathrm{ha}^{-1} \mathrm{yr}^{-1}$, respectively, in Fig. 6). However, the best examples of farms with a high $\mathrm{N}$ efficiency were probably the twelve dairy farms in NL, which all showed a lower $\mathrm{N}$-surplus compared to the average line, even though they were a significant source of $\mathrm{N}$ losses (Fig. 6), and an average $\mathrm{N}$-surplus not differing significantly from the average in IT, FR and DK (Fig. 4). However, as discussed later, there are important lessons to be learned from these systems in relation to options for $\mathrm{N}$ mitigation. Finally, it should be mentioned that landless poultry farming, with the largest $\mathrm{N}$ surplus in the UK landscape, was not included in Fig. 6, which only contains land-based systems. 


\subsection{Example of the effect of N-mitigation measures in the Danish landscape}

A special case study from the Danish landscape is used here to illustrate the use of the N-balance method for $\mathrm{N}$ mitigation measure evaluation. Based on results from Dalgaard et al. (2002a), the average N-surplus from farms in the Danish landscape for the period 1994-1998 was $186 \pm 46 \mathrm{~kg} \mathrm{~N}$ $\mathrm{ha}^{-1} \mathrm{yr}^{-1}$ (using the same method as the current study, but excluding about $10 \%$ of the agricultural area that was used for set-aside during that period in order to receive EU subsidies) (Levin and Jepsen, 2010).

These results were used to evaluate the effects of measures implemented in general legislation between 1998 and 2008 to increase $\mathrm{N}$ efficiency, which were expected to have an impact on farm $\mathrm{N}$ surpluses in this particular landscape (i.e., regulation of maximum farm livestock densities, statutory norms for crop $\mathrm{N}$ fertilisation set to $10 \%$ below the economic optimum, and obligatory farm $\mathrm{N}$ accounts with specified demands for manure $\mathrm{N}$ utilisation and thereby restrictions on fertiliser imports, etc. (see Kronvang et al., 2008). The average $\mathrm{N}$ surplus in the landscape was reduced by about $22 \%$ over the period when compared to the results from Fig. 4, which include insignificant areas of set-aside $(<1 \%)$ and represent a total livestock and crop production in 2008 similar to the 1998 situation. However, because of the large uncertainty and variability between farms in such a small study area, the general reduction was not statistically significant $(p<0.07)$. This suggests that there was a larger reduction on farms with a high livestock density compared with farms with a low livestock density and lower manure application rates.

The Danish N legislation has specifically focused on measures to reduce $\mathrm{N}$ emissions from livestock farms and manure systems (Kronvang et al., 2008), and the new dataset and $\mathrm{N}$-surplus accounting methods presented an opportunity to make an independent test of the effect of such measures. Consequently, the $\mathrm{N}$-surplus reductions were tested separately for farms with less and more than $1 \mathrm{LSU} \mathrm{ha}^{-1} \mathrm{yr}^{-1}$, respectively (where 1 livestock unit (LSU) equals $100 \mathrm{~kg}$ $\mathrm{N}$ in manure produced ex store, or distributed during grazing). No significant difference $(p=0.80)$ was identified for farms with $<1 \mathrm{LSU} \mathrm{ha}^{-1} \mathrm{yr}^{-1}$, but for farms with $>1 \mathrm{LSU} \mathrm{ha}^{-1} \mathrm{yr}^{-1}$ there was a significant difference $(p<$ $0.01)$, both when set-aside areas were included and when they were not (Pedersen, 2011).

\section{Discussion}

The results show that the farm N-balance method presented is useful for comparing farming systems in Europe, identifying hotspots for $\mathrm{N}$ emissions, and evaluating effects of $\mathrm{N}$ mitigation measures. In particular, it is interesting that this method enabled comparisons across a large range of bio- physical conditions, from Scotland in the north to Italy in the south. This indicates that the $\mathrm{N}$-surplus may be used as an independent indicator for validation of measured and modelled $\mathrm{N}$ emissions in agricultural landscapes. Moreover, the study highlights hotspots in the form of critically high $\mathrm{N}$ balances at the farm level in different landscapes, and shows the different methods and assumptions used to perform the $\mathrm{N}$ balance evaluation procedure in these different regions. This provides a background for region specific development of measures for $\mathrm{N}$ emission reduction at both farm and landscape scale. Nonetheless, there are important uncertainties, shortcomings and potentials for further development in relation to the $\mathrm{N}$ balance method and its application, which we will discuss in more detail in the following.

\subsection{The farm $\mathrm{N}$ inventory method}

Like many previous farm N-balance studies (for example Beukes et al., 2012; Cameron et al., 2012; Dalgaard et al., 2011, 2002a, 1998; Halberg, 1999; Shingo and Kiyotada, 2012; Spiess, 2011), the present calculations were based on a set of standard values for $\mathrm{N}$ contents in the classes of farm inputs and products defined (Tables 1, 2). However, although these standards were reviewed and agreed among all landscape partners, they involve significant uncertainties, and differences between $\mathrm{N}$ contents of materials in the different landscapes and farming systems must be expected. This uncertainty was reduced via the option in each landscape to use specific values for product subclasses (for example a specific $\mathrm{N}$ content value for wheat cereals instead of the generally lower standard class value for cereals of $16.3 \mathrm{~kg} \mathrm{~N} \mathrm{Mg}^{-1}$ ). However, this option was only used by local partners in a few cases, suggesting that standard values were widely considered to be adequate. However, when assessing the results it must be remembered that the largest fodder imports were in landscapes of FR, NL and PL. Therefore, any inaccuracy in the import of $\mathrm{N}$ in fodder would have had the largest impact in these three cases. The same argument holds for the large amounts of manure which are exported from or imported to the landscapes.

Another critical point may be the reliance on values from a single year's $\mathrm{N}$ balances, thus ignoring potential annual variations. Significant differences between years have previously been revealed (Hansen and Kyllingsbæk, 2007), especially in very dry years with higher $\mathrm{N}$ surpluses related to crop yield depressions. Therefore, it is important to state that all the results included here were from years without extreme yields or weather conditions, and as a consequence, we consider that the results may be interpreted as typical for the farms and landscapes studied. This also includes the values for N-fixation which are similar to those reported by Smil (1999) and Spiess (2011). Nevertheless, it must be emphasised that, at least at farm level, the $\mathrm{N}$-fixation values are approximate and uncertain estimates, rather than measured values, and that the sensitivity to changes in these estimates 
is quite important for the interpretation of the final N-balance results. Especially in low input systems, the accuracy of estimates of $\mathrm{N}$ fixation will have a large impact on the accuracy of the $\mathrm{N}$-balance. As stated, one estimate for $\mathrm{N}$ fixed via pulses $\left(100 \mathrm{~kg} \mathrm{~N} \mathrm{ha}^{-1} \mathrm{yr}^{-1}\right)$ and two $\mathrm{N}$ levels for legumes in grassland (150 or $20 \mathrm{~kg} \mathrm{~N} \mathrm{ha}^{-1} \mathrm{yr}^{-1}$ ) are very coarse estimates covering a considerably larger variation. In a study that relies on farmer interviews, it is not easy to get good estimates of the roughage yields or the proportion of legumes, neither in the harvested roughage nor in the grazed areas. Consequently, this large uncertainty should be considered when assessing estimated surpluses and N-efficiencies. This is particularly the case for the results in DK, FR and PL, where some cattle farms have extensive areas with $\mathrm{N}$-fixing grass/clover, compared to the grassland in NL, which Heij and Erismann (1997) considered to have a much lower average $\mathrm{N}$ fixation rate of $20 \mathrm{~kg} \mathrm{~N} \mathrm{ha}^{-1} \mathrm{yr}^{-1}$. This uncertainty and potentially skewed distribution should be kept in mind when interpreting the results of Figs. 4 to 6 .

Moreover, as mentioned in Sect. 2.2, the $\mathrm{N}$ deposition estimates taken from the EMEP $(2008,2010)$ represent average values for the relevant $50 \times 50 \mathrm{~km}$ grid and may be underestimations, especially for local areas and farms with a high livestock density. This may be the case for NL, which according to Fig. 5 had the highest measured ammonia concentration, even though the EMEP estimated the highest $\mathrm{N}$ deposition to occur in the French landscape. According to Durand et al. (2010), the EMEP deposition value for FR was also set too low. In reality, farm level $\mathrm{N}$ deposition may therefore be underestimated for livestock farms and for farms near large livestock facilities, such as the large poultry farms in the UK (Skiba et al., 2006; Dragosits et al., 2002). Conversely, it may be overestimated for low livestock density farms such as the large semi-natural areas with extensive sheep grazing in UK, or the coastal vegetable farms in IT where fertilisation, although at a very high level, was based on synthetic fertilisers with a relatively low $\mathrm{N}$ emission compared to manurebased and livestock-related systems (Oenema et al., 2011). Moreover, both these farm types were located in the western parts of the landscape. For the Italian landscape, westerly winds off the Mediterranean Sea dominate, so the actual $\mathrm{N}$-deposition values may be lower than expected for the particular farming systems. Consequently, as discussed below, the inclusion of such landscape heterogeneity and boundary condition effects should be a topic for further research.

\subsection{Landscape differences in farm $\mathrm{N}$ surplus and efficiency}

The general $\mathrm{N}$ balance results of Fig. 4 show an interesting pattern, with the highest feed imports and animal production in the grassland and forage crop-dominated landscapes of the central Atlantic biogeographical zone in Fig. 1 (NL and FR, and the landless poultry farming systems in UK). By contrast, the landscapes of PL and DK (respectively in the mid- dle of and on the border to the Continental zone) represent more cereal-based production systems, with less intensive livestock production and consequently lower net feed import. The $\mathrm{N}$ surplus was also generally lower in these landscapes. Finally, the landscapes of IT and UK (respectively in the Mediterranean and the northern Atlantic zones of Fig. 1) represent more heterogeneous farm $\mathrm{N}$ balances that vary across a wide range of systems: from large water buffalo and poultry farms with very high feed imports and export of manure, and vegetable farms with a high crop export but a large import of fertiliser, to extensive beef and sheep farms with nonfertilised semi-natural grasslands and only marginal $\mathrm{N}$ exports per land area.

If $\mathrm{N}$ efficiency in accordance with Eq. (2) is defined as net $\mathrm{N}$ output in products sold divided by net $\mathrm{N}$ inputs purchased by the farmer, the highest $\mathrm{N}$ efficiency was found in FR and NL ( $32 \%$ and $31 \%$, respectively), whereas the average efficiency was $24 \%$ for IT, $21 \%$ and $19 \%$ for PL and DK, respectively, and only $5 \%$ on average for the extensive, land-based farming systems in UK. If the approximate figures from the poultry farming were included, the average $\mathrm{N}$ efficiency would be about $60-80 \%$ for the UK landscape. However, this value is very difficult to compare with those from the other landscapes because of the large manure export, which is here considered a product, but would lead to $\mathrm{N}$ surpluses and $\mathrm{N}$ pollution in the areas the manure was exported to. Thus, the systems with the highest $\mathrm{N}$ inputs are also those which are most $\mathrm{N}$-efficient, even though they also have large $\mathrm{N}$ surpluses and losses to the environment, and this contrasts with much of the thinking about regulations that is often input-related.

This study primarily focuses on local (farm or landscape level) effects of N-losses in the form of ammonia or nitrate, but also the more global consequences in the form of $\mathrm{N}$-related greenhouse gas emissions are important. For the evaluation of such global consequences of $\mathrm{N}$-surplus, $\mathrm{N}$ efficiency or $\mathrm{N}$ costs in the form of $\mathrm{N}$ losses associated with the production of the fodder and manure imported to the farm must be included (Bleken et al., 2005). In the present study, the highest N-efficiency was found in FR and the lowest in UK. However, the French farms had the highest fodder import and the Scottish the lowest (Fig. 4). Consequently, if the N-costs associated with fodder imports were included, the conclusions might have been the reverse. Similarly, in the calculation of global consequences of $\mathrm{N}$ use, manure $\mathrm{N}$ removed from a landscape ought instead be a part of the surplus and not calculated as $\mathrm{N}$ in products.

In general, overall $\mathrm{N}$ efficiencies in the landscapes studied are relatively low, with less than one third of the $\mathrm{N}$ inputs utilized in the products sold; and this even without the inclusion of $\mathrm{N}$ inputs from the atmosphere in the equation. This would certainly indicate room for improvement, and based on the large differences between the $\mathrm{N}$-surplus of the average and the most modern and $\mathrm{N}$-efficient farms, it was concluded that 
$\mathrm{N}$-surplus reductions of $25-50 \%$ as compared to the present level were realistic in all landscapes.

It is important to note the large uncertainties in the Nsurplus and $\mathrm{N}$-efficiency figures. To be able to draw general conclusions in line with those discussed above, a large sample size is needed. The farm sample size was small, in particular for DK with 13 farms, and FR with 17 farms. For DK there seemed to be a trend towards relatively lower $\mathrm{N}$ surpluses from large and full-time farms compared with the relatively large values of small hobby farms. The farm sample was, however, too small to document this statistically, even though this effect has been shown in previous studies (Dalgaard et al., 2002a, 2011) and follows the general trend of higher $\mathrm{N}$ efficiencies for intensive farming systems. Moreover, in DK two of the largest and most N-efficient farms in the study had most of their fields outside the actual watershed of the study landscape, and one of the farms located in the middle of the watershed closed its dairy production immediately before the study year, but kept some heifers, and some remaining manure was spread within the study year. This affected the estimates of average $\mathrm{N}$ balances and illustrates the importance of local dynamics, and the uncertainties and peculiarities of studies in specific landscapes. Future studies of landscape $\mathrm{N}$ balances should include a larger number of farms to counteract such effects. In contrast, we consider the farming systems of NL more uniform, whereby even the small sample of only 12 farms is likely to have given representative results for the central dairy farming area of the NL landscape. The two water buffalo farms included in IT and the large poultry farms in the UK must be considered special cases, and more data from similar farms are needed to draw general conclusions for the $\mathrm{N}$ balance of such systems.

\subsection{N-surplus hotspots and effects of landscape hetero- geneity}

This study includes farm $\mathrm{N}$-surpluses calculated at the farm gate, i.e., from inputs and outputs recorded in the annual farm accounts and from estimated atmospheric inputs (Fig. 3). The advantage of this approach is that the farm $\mathrm{N}$ balances are largely based on measured flows and are thus considered robust. However, a disadvantage of this whole-farm method is that the $\mathrm{N}$-surpluses can only be used as a general indicator of $\mathrm{N}$ lost or accumulated within the whole farming system and do not indicate whether $\mathrm{N}$ is lost to the aquatic environment or to the atmosphere, and from which component of the farm the loss occurs. The data collected from the farms would have permitted the use of an alternative approach in which the farm $\mathrm{N}$ surplus was calculated from the $\mathrm{N}$-inputs and outputs from individual fields, livestock houses and manure storages. While this would have permitted the $\mathrm{N}$ surplus to be partitioned between the farm components (principally between the animal housing/manure storage and the fields), the $\mathrm{N}$ input and output data at the component scale were considered too uncertain to justify the use of this approach. The uncertainty in the data arises both from uncertainties in the measured flow of material (e.g., manure, crop yield) and the difficulties in measuring changes in the short-term storage of $\mathrm{N}$ in the components (mainly manure in animal housing and storage). The latter uncertainties would largely disappear if data could be collected over several years.

To partition the $\mathrm{N}$-surplus into types of losses (nitrate, ammonia, nitrous oxide, etc.) and soil $\mathrm{N}$ accumulation/erosion, a much more detailed approach would be needed, including modelling and partitioning of $\mathrm{N}$-inputs and $\mathrm{N}$-outputs to fields, livestock houses and manure systems (Dalgaard et al., 2011; Happe et al., 2011; Vogt et al., 2012), as well as the inclusion of $\mathrm{N}$ exchange dynamics with non-agricultural areas (Drouet et al., 2012). This would make it possible to geographically map hotspots for $\mathrm{N}$-sources (and $\mathrm{N}$-sinks) to these particular compartments within the landscape. Such an approach would be worthwhile, since the identification of hotspots would enable mitigation measures to be targeted to these areas, which is likely to result in a more cost-effective reduction in $\mathrm{N}$ pollution. However, the experience from the current study is that it is difficult to collect the more detailed data in the quantity and with the quality that is necessary. The uncertainties could be reduced by increasing the number of farms included in the survey, but this would also add significantly to the cost; the more detailed data are either not collected by the farmer, so the cost of collecting the individual data is high, or are not collected by the farmers in a standard format.

A second difficulty encountered in this study was how to treat farms that exported significant quantities of manure to areas outside the study landscapes. One option would be to increase the area of the landscape to include the recipient areas. This might already be necessary to combat measurement uncertainties (see above) but for areas with high livestock densities, the pressure from national and EU legislation is forcing farmers to export manure significant distances (e.g., in the Netherlands), so this is likely to be too expensive. An alternative would be to identify the recipient areas and include them in the study, either by surveying or by using modelling or appropriate emission/loss factors to account for the associated losses to environment.

\subsection{Landscape-scale measurements and sustainable farm $\mathrm{N}$ management designs}

The correlation between the average farm $\mathrm{N}$-surplus data collected for the relatively small landscapes of around $5 \times 5 \mathrm{~km}$ or smaller, and the independent measurement results of atmospheric ammonia and soil and groundwater nitrate concentrations in the landscapes provide an indication of the usefulness of $\mathrm{N}$-surplus for informing on N-pollution problems (Fig. 5). The correlation between $\mathrm{N}$-surplus and nitrate concentrations was the strongest, which was expected because the nitrate measurements relate directly to soil and groundwater within the landscape, whereas the ammonia 
concentrations relate to emissions from farms both within and outside the actual landscapes. General correlations between trends in farm $\mathrm{N}$-surplus and nitrate concentrations in Danish groundwater for the period 1950-2007 have been published by Hansen et al. (2011, 2012), but the potential remains for further investigation of more detailed landscapelevel effects and correlations (Bende-Michl et al., 2011). In this context, the present results are promising for further investigation of correlations between the site-based $\mathrm{N}$ measurements carried out in the landscapes during the NitroEurope project (e.g., Schelde et al., 2012; Wohlfart et al., 2012; Vogt et al., 2012) and the geographical location of farms and derived $\mathrm{N}$ surplus and $\mathrm{N}$ sources from specific fields, livestock houses, manure stores, etc., as well as the transfer to $\mathrm{N}$-sinks in the landscapes (Drouet et al., 2012).

There is further potential to protect sensitive semi-natural areas vulnerable to $\mathrm{N}$ pollution, not only through increasing $\mathrm{N}$-efficiency but also via landscape-level spatial planning, by for example planting of hedgerows and trees along water courses (Christen and Dalgaard, 2012) or around near livestock facilities to re-capture or disperse ammonia emitted (Dragosits et al., 2006). For future studies, it would therefore be interesting to investigate this potential within the landscape sites presented here. Such analyses could also include an investigation of how $\mathrm{N}$ losses from local hotspots in the landscape cascade. For example, $\mathrm{N}$ from manure is volatilised as ammonia, some of which will deposit to seminatural areas or agricultural land, wherefrom it may be either recycled in the system via harvest or eventually be lost in the form of various $\mathrm{N}$ compounds. All these $\mathrm{N}$ pathways are complex and include important feedback mechanisms, and taking them into account in agricultural management may help to mitigate $\mathrm{N}$ pollution problems and improve production $\mathrm{N}$ efficiency.

An assessment of the effects of $\mathrm{N}$-mitigation measures in the Danish study landscape 1998-2008 exemplifies the results of such measures on N-surplus. Significant reductions in the $\mathrm{N}$ surplus from livestock farms were documented due to better utilisation of $\mathrm{N}$ contained in livestock manures over the period. Consequently, in the Danish landscape there was a tendency to less use of synthetic fertilisers in 2008, with a higher farm-level use of manures. However, such a tendency was apparently not found in the farm level datasets of any of the other landscapes, indicating potentials for a better utilisation of livestock manures similar to that achieved in the Danish area via the use of technologies and management for improving manure $\mathrm{N}$ use to replace synthetic fertilisers. The present study only covered results from one year, and did not include a closer investigation of this, but further investigations would be interesting for future landscape studies. Moreover, there was a slight tendency for a non-linear, exponential relationship between land-based $\mathrm{N}$ input and $\mathrm{N}$ surpluses in Fig. 6, indicating a potentially better $\mathrm{N}$-utilisation via a more uniform distribution of manures and other types of $\mathrm{N}$ inputs from hotspot farms to other farms with less inten- sive N-input regimes (Dalgaard et al., 2011). As the results show a positive relationship between farm $\mathrm{N}$ surpluses and landscape $\mathrm{N}$ concentrations in the air, soil and water, it can be surmised that a reduction in surpluses will lead to a reduction in $\mathrm{N}$ losses to the environment. A take-home message must be that methods are available to identify and evaluate levels of $\mathrm{N}$ surplus in specific landscapes, and to estimate the overall effects of measures tailored to reduce farm $\mathrm{N}$ losses.

\section{Conclusions}

The method presented here to calculate farm $\mathrm{N}$ surplus as an indicator of $\mathrm{N}$ losses and of the potential for improved $\mathrm{N}$ management was applied to six agricultural landscapes in Europe.

On average, the highest $\mathrm{N}$ surpluses for the study period were found in the most livestock-intensive landscapes of FR, NL, and IT, where intensively-fertilized, multiple annual crop cycles in vegetable production also contributed significantly to the $\mathrm{N}$ surplus. However, all landscapes showed hotspots from livestock farms, including a special case of large "landless" poultry farming in UK. For future studies the question will be how to include indirect $\mathrm{N}$ surplus and $\mathrm{N}$ emissions from such farms with a large export of manure out of the landscape.

Positive correlations between average landscape farm $\mathrm{N}$ surpluses and measured concentrations of ammonia in the air, nitrates in soils, and nitrates in groundwater were found, indicating that $\mathrm{N}$ surpluses may be used as an independent dataset for validation of measured and modelled $\mathrm{N}$ emissions in agricultural landscapes. Such significant couplings of reductions in $\mathrm{N}$ surplus with groundwater nitrates have previously been published for Denmark (Hansen et al., 2011, 2012), consistent with the present results from the morainesoil-dominated landscapes in PL, FR and DK. In this context, an average $22 \% \mathrm{~N}$ surplus reduction was achieved in DK from 1998-2008, attributable to measures to reduce $\mathrm{N}$ surplus from livestock farms.

In all six study landscapes, a large variation in the farm $\mathrm{N}$ surplus was found, and thus a large potential for $\mathrm{N}$-surplus reductions of up to 25-50\% compared with the current level. The $\mathrm{N}$-surplus method was shown to be effective for comparing and synthesizing farm $\mathrm{N}$ emissions and the potential of $\mathrm{N}$ mitigation options. The method is recommended for use in combination with other methods for the assessment of landscape $\mathrm{N}$ emissions and farm $\mathrm{N}$ efficiency, including more detailed $\mathrm{N}$ sink and $\mathrm{N}$ source hotspot mapping, measurements and modelling.

Acknowledgements. The authors would like to thank The European Commission and Aarhus University for financially supporting the NitroEurope research project (www.NitroEurope.eu), and the Danish Nitrogen Mitigation Assessment project (DNMARK), within which the research was undertaken. Moreover, thanks are 
directed to all who contributed to the data collection, carried out farm interviews and populated the large database for the six landscapes, and the farmers for taking the time to answer all our questions and let us carry out measurements on their land, and special thanks to $\mathrm{PhD}$ student Siri Pugesgaard for help with farm interviews and database work, and to Rosa Maria Hauge Pedersen, for her excellent bachelor project, including the statistical analyses of differences between farm $\mathrm{N}$ balances in the Danish Landscape 1994-1998 and 2008. Finally, thank you to the NERC Centre for Ecology \& Hydrology (http://www.ceh.ac.uk) and project leader Mark A. Sutton for an admirable NitroEurope project coordination and development.

Edited by: S. Reis

\section{References}

Alcamo, J. and Olesen, J. E.: Life in Europe Under Climate Change, ISBN 978-1-4051-9619-2, Wiley Blackwell, Chichester, UK, 2012.

Bartoli, M., Racchetti, E., Delconte, C. A., Sacchi, E., Soana, E., Laini, A., Longhi, D., and Viaroli, P.: Nitrogen balance and fate in a heavily impacted watershed (Oglio River, Northern Italy): in quest of the missing sources and sinks, Biogeosciences, 9, 361373, doi:10.5194/bg-9-361-2012, 2012.

Bende-Michl, U., Volk, M., Newham, L., Harmel, D., and Dalgaard, T.: Monitoring strategies and scale appropriate hydrologic and biogeochemical modelling for natural resource management. Short communication, Environ. Model. Softw., 26, 538-542, 2011.

Beukes, P. C., Scarsbrook, M. R., Gregorini, P., Romera, A. J., Clark, D. A., and Catto, W.: The relationship between milk production and farm-gate nitrogen surplus for the Waikato region, New Zealand, J. Env. Man., 93, 44-51, 2012.

Bienkowski, J., Jankowiak, J., Kedziora, A., and Wasilewski, J.: Possibilities for the Development of Mixed Crop-Beef Farming in the Koscian Region Based on Natural Fodder Resources. Results from the MEA-Scope Case Study in Poland, in: Rural Landscapes and Agricultural Policies in Europe, edited by: Piorr, A. and Müller, K., 269-283, Springer Verlag, Berlin, 2009.

Billen, G., Garnier, J., Thieu, V., Silvestre, M., Barles, S., and Chatzimpiros, P.: Localising the nitrogen imprint of the Paris food supply: the potential of organic farming and changes in human diet, Biogeosciences, 9, 607-616, doi:10.5194/bg-9-6072012, 2012.

Bleken, M. A., Steinshamn, H., and Hansen, S.: High nitrogen costs of dairy production in Europe: Worsened by intensification, Ambio, 34, 598-606, 2005.

Bouraoui, F., Turpin, N., and Boerlen, P.: Trend analysis of nutrient concentrations and loads in surface water in an intensively fertilized watershed, J. Environ. Quality, 28, 1878-1885, 1999.

Brink, C. and van Grinsven, H. V.: Costs and Benefits of nitrogen in the environment, in: The European Nitrogen Assessment, edited by: Sutton, M. A., Howard, C. M., Erisman, J. W., Billen, G., Bleeker, A., Grennfelt, P., Grinsven, H., and Grizzetti, B., Cambridge University Press, pp. 513-540, 2011.

Cameron, J. P., Gourley, A. S. R., Powell, J. M., and Mark, J.: Nitrogen use efficiency and manure management practices in contrast- ing dairy production systems, Agriculture, Ecosystems Environ., 147, 73-81, 2012.

Cellier, P., Durand, P., Hutchings, N., Dragosits, U., Theobald, M., Drouet, J. L., Oenema, O., Bleeker, A., Breuer, L., Dalgaard, T., Duretz, S., Kros, J., Loubet, B., Olesen, J. E., Mérot, P., Viaud, V., de Vries, W., and Sutton, M. A.: Dispersion and fate of nitrogen in rural landscapes, in: The European Nitrogen Assessment. Chapter 11, edited by: Sutton, M. A., Howard, C. M., Erisman, J. W., Billen, G., Bleeker, A., Grennfelt, P., Grinsven, H., and Grizzetti, B., pp. 229-248 Cambridge University Press, 2011.

Christen, B. and Dalgaard, T.: Buffers for biomass production in temperate European agriculture: A review and synthesis on function, ecosystem services and implementation, Biomass and Bioenergy, in press, doi:10.1016/j.biombioe.2012.09.053, 2012.

Dalgaard, T., Halberg, N., and Kristensen, I. S.: Can organic farming help to reduce N-losses? Experiences from Denmark, Nutrient Cycling in Agroecosystems, 52, 277-287, 1998.

Dalgaard, T., Heidman, T., and Mogensen, L.: Potential N-losses in three scenarios for conversion to organic farming in a local area of Denmark, European Journal of Agronomy, 16, 207-221, $2002 \mathrm{a}$.

Dalgaard, T., Rygnestad, H., Jensen, J. D., and Larsen, P. E.: Methods to map and simulate agricultural activity at the landscape scale, Danish J. Geogr., 3, 29-39, 2002 b.

Dalgaard, T., Kjeldsen, C., Jørgensen, M. S., Hutchings, N., Mogensen, L., Osuch, A., Damgaard, M., Happe, K., and Piorr, A.: Scaling from Farm to Landscape - a Bottom-up Methodology for the Modelling and Mapping of Farm Nitrogen Surpluses, in: Rural Landscapes and Agricultural Policies in Europe, edited by: Piorr, A. and Müller, K., p. 175-190, Springer Verlag, Berlin, 2009.

Dalgaard, T., Hutchings, N., Dragosits, U., Olesen, J. E., Kjeldsen, C., Drouet, J. L., and Cellier, P.: Effects of farm heterogeneity on modelling and upscaling of nitrogen losses and greenhouse gas emissions in agricultural landscapes, Environ. Pollut., 159, 3183-3192, 2011.

De Vries, W., Cellier, P., Erisman, J. W., and Sutton, M. A.: Assessment of nitrogen fluxes to air and water from site scale to continental scale: an overview, Environ. Pollut., 159, 3143-3148, 2011.

Dise, N. B., Ashmore, M., Belyazid, S., Bleeker, A., Bobbink, R., de Vries, W., Erisman, J. W., Spranger, T., and van den Berg, C. J. S. L.: Nitrogen as a threat to European Terrestical Biodiversity, in: The European Nitrogen Assessment, edited by: Sutton, M. A., Howard, C. M., Erisman, J. W., Billen, G., Bleeker, A., Grennfelt, P., Grinsven, H., and Grizzetti, B., Chapter 20, p. 463-494, Cambridge University Press, 2011.

Dragosits, U., Theobald, M. R., Place, C. J., Lord, E., Webb, J., Hill, J., ApSimon, H. M., and Sutton, M. A.: Ammonia emission, deposition and impact assessment at the field scale: a case study of sub-grid spatial variability, Environ. Pollut., 117, 147-158, 2002.

Dragosits, U., Theobald, M. R., Place, C. J., Simon, H. M., and Sutton, M. A.: Spatial planning at the landscape level to mitigate the effects of atmospheric ammonia deposition, J. Environ. Sci. Policy, 9, 626-638, 2006.

Dragosits, U. and Dalgaard, T.: Notes for filling in the NEU C4 Landscape Questionnaire and Database. Recommended approach for completing the landscape inventory, NitroEurope Deliverable report D4.1.2, 10 p. (www.NitroeEurope.eu), Centre for 
Ecology and Hydrology, Scotland, 2008.

Dragosits, U., Dalgaard, T., Hutchings, N., Durand, P., Bienkowski, J., Magliulo, V., Frumau, K. F. A., McDonald, C., Murray, S., Luk, J., Olesen, J. E., Pugesgaard, S., Drouet, J.-L., Akkal, N., and Cellier, P.: How (not) to produce detailed farm management inventories for landscape scale nitrogen modelling, Paper presented at the NitroEurope Open Conference "Nitrogen \& Global Change: Key findings - future challenges", Edinburgh, Conference abstract, 2 pp., available at: http://nitrogen.ceh.ac.uk/nitrogen2011/_oral_ presentations/S12_3_Dragosits.pdf, 11-15 April 2011.

Drouet, J.-L., Maury, O., Dalgaard, T., Dragosits, U., Theobald, M. R., Durand, P., Sutton, M. A., and Cellier, P.: An integrated database for European agricultural landscapes. Proceedings of the Conference "Nitrogen and Global Change, Key findings, future challenges", 11-14 April 2011, Edinburgh, UK, 2011.

Drouet, J.-L., Duretz, S., Durand, P., and Cellier, P.: Modelling the contribution of short-range atmospheric and hydrological transfers to nitrogen fluxes, budgets and indirect emissions in rural landscapes, Biogeosciences, 9, 1647-1660, doi:10.5194/bg9-1647-2012, 2012.

Durand, P.: Simulating nitrogen budgets in complex farming systems using INCA: calibration and scenario analyses for the Kervidy catchment (W. France), Hydrol. Earth Syst. Sci., 8, 793802, doi:10.5194/hess-8-793-2004, 2004.

Durand, P., Akkal, N., Flechard, C., Drouet, J., Hamon, Y., Molenat, J., Hassouna, M., and Cellier, P.: Nitrogen fluxes and budgets in a NEU C4 site (Kervidy-Naizin, France) with high nitrogen surplus: measurements and modelling, available at: http://nitrogen. ceh.ac.uk/solothurn/NEU_Booklet_Solothurn_Feb_2010.pdf, in: Reactive Nitrogen and the European Greenhouse Gas Balance. Open Science Conference Proceedings, Solothurn, Switzerland, section 4.7, p. 75, 2010.

EMEP: Transboundary Acidification, Eutrophication and Ground Level Ozone in Europe in 2006, ISSN 1504-6109, available at: http://webdab.emep.int/Unified_Model_Results/ userguide_frame.html, EMEP Status Report 1/2008, 2008.

EMEP: Transboundary Acidification, Eutrophication and Ground Level Ozone in Europe in 2008, ISSN 1504-6109, available at: http://webdab.emep.int/Unified_Model_Results/ userguide_frame.html, EMEP Status Report 1/2010, 2010.

European Environmental Agency: Europe's biodiversity - biogeographical regions and seas, available at: http://www.eea. europa.eu/publications/report_2002_0524_154909, EEA Report No 1/2002. Copenhagen, 2002.

European Environmental Agency: Agriculture and environment in EU-15 - the IRENA indicator report, EEA Report No 6/2005 ISBN 92-9167-779-5, ISSN 1725-9177, EEA, Copenhagen, 2005.

EUROSTAT: Europe in Figures. Farm structure statistics, EUROSTAT Yearbook, ISBN: 978-92-79-18414-7, available at: http://epp.eurostat.ec.europa.eu/statistics_explained/index.php/ Farm_structure, European Statistical Bureau, Luxembourg, 2011.

Galloway, J. N., Aber, J. D., Erisman, J. W., Seitzinger, S. P., Howarth, R. W., Cowling, E. B., and Cosby, B. J.: The Nitrogen Cascade, BioScience, 53, 341-356, 2003.

Halberg, N.: Indicators of resource use and environmental impact for use in a decision aid for Danish Livestock Farmers. Agricul- ture, Ecosystems and Environment, 76, 17-30, 1999.

Hansen, J. (Ed.): Arealanvendelse og landskabsudvikling. Fremtidsperspektiver for natur, jordbrug, miljø og arealforvaltning, http://web.agrsci.dk/djfpublikation/djfpdf/djfma110.pdf, DJF report no. 110, Markbrug (with English summaries), 2004.

Hansen, J. and Kyllingsbæk, A.: Development in nutrient balances in Danish agriculture 1980-2004, Nutr Cycl Agroecosyst, 79, 267-280, 2007.

Hansen, B., Thorling, L., Dalgaard, T., and Erlandsen, M.: Trend reversal of nitrate in Danish groundwater - a reflection of agricultural practices and nitrogen surpluses since 1950, Environ. Sci. Technol., 45, 207-234, 2011.

Hansen, B., Dalgaard, T., Thorling, L., Sørensen, B., and Erlandsen, M.: Regional analysis of groundwater nitrate concentrations and trends in Denmark in regard to agricultural influence, Biogeosciences, 9, 3277-3286, doi:10.5194/bg-9-3277-2012, 2012.

Happe, K., Hutchings, N., Dalgaard, T., and Kellermann, K.: Modelling the interactions between regional farming structure, nitrogen losses and environmental regulation, Agricultural Systems, 104, 281-291, 2011.

Heij, G. H. and Erismann, J. W.: Acid Atmospheric Deposition and Its Effects on Terrestrial Ecosystems in The Netherlands, Studies in Environmental Sciences 69, ISBN 0-444-82037-X, Elsevier, Amsterdam, 1997.

Hewett, C. J. M., Quinn, P. F., Heathwaite, A. L., Doyle, A., Burke, S., Whitehead, P. G., and Lerner, D. N.: A multi-scale framework for strategic management of diffuse pollution, Environ. Model. Softw., 24, 74-85, 2009.

Høgh-Jensen, H. and Schjørring, J. K.: Measurement of biological dinitrogen fixation in grassland: Comparison of the enriched $15 \mathrm{~N}$ dilution and the natural $15 \mathrm{~N}$ abundance methods at different nitrogen application rates and defoliation frequencies, Plant and Soil, 166, 2, 153-163, 1994.

Hutchings, N., Dalgaard, T., Rasmussen, B. M., Hansen, J. F., Dahl, M., Jørgensen, L. F., Ernstsen, V., von Platen-Hallermund, F., and Pedersen, S. S.: Watershed nitrogen modelling, in: Controlling nitrogen flows and losses, edited by: Hatch, D. J., Chadwick, D. R., Jarvis, S. C., and Roker, J. A., Wageningen Academic Publishers, ISBN 90-7699-984-34, p. 47-53, 2004.

Hutchings, N. J., Reinds, G. J., Leip, A., Wattenbach, M., Bienkowski, J. F., Dalgaard, T., Dragosits, U., Drouet, J. L., Durand, P., Maury, O., and de Vries, W.: A model for simulating the timelines of field operations at a European scale for use in complex dynamic models, Biogeosciences, 9, 4487-4496, doi:10.5194/bg-9-4487-2012, 2012.

INRA: Kervidy-Naizin site. AgrHyS Environment Research Observatory, http://www.inra.fr/ore_agrhys_eng, http: //www.inra.fr/ore_agrhys_eng/presentation/site_et_equipement/ site_de_kervidy_naizin/sols_et_lithologie, Institute National a la Recherche Agronomique, Paris, 2008.

Kronvang, B., Andersen, H. E., Børgesen, C. D., Dalgaard, T., Larsen, S. E., Bøgestrand, J., and Blicher-Mathiasen, G.: Effects of policy measures implemented in Denmark on nitrogen pollution of the aquatic environment, Environ. Sci. Policy, 11, 144$152,2008$.

Lassaletta, L., Romero, E., Billen, G., Garnier, J., García-Gómez, H., and Rovira, J. V.: Spatialized N budgets in a large agricultural Mediterranean watershed: high loading and low transfer, Biogeosciences, 9, 57-70, doi:10.5194/bg-9-57-2012, 2012. 
Leip, A., Marchi, G., Koeble, R., Kempen, M., Britz, W., and $\mathrm{Li}, \mathrm{C}$.: Linking an economic model for European agriculture with a mechanistic model to estimate nitrogen and carbon losses from arable soils in Europe, Biogeosciences, 5, 73-94, doi:10.5194/bg-5-73-2008, 2008.

Levin, G. and Jepsen, M. R.: Abolition of set-aside schemes, associated impacts on habitat structure and modelling of potential effects of cross-farm regulation, Ecol. Model., 221, 2728-2737, 2010.

Molenat, J., Gascuel-Odoux, C., Davy, P., and Durand, P.: Temporal and spatial dynamics of the groundwater in small catchment in relation to soil topography and stream discharge, Hydrol. Processes, 19, 901-920, 2004.

Molenat, J., Gascuel-Odoux, C., Ruiz, L., and Gruau, G.: Role of water table dynamics on stream nitrate export and concentration in agricultural headwater catchment (France), J. Hydrol., 348, 363-378, 2008.

Neumann, K., Verburg, P. H., Elbersen, B., Stehfest, E., and Woltjer, G. B.: Multi-scale scenarios of spatial-temporal dynamics in the European livestock sector, Agriculture, Ecosystems and Environment, 140, 88-101, 2011.

NitroEurope: Official Homepage for the NitroEurope Integrated Project: The nitrogen cycle and its influence on the European greenhouse gas balance, available at: www.NitroEurope.eu, Centre for Ecology and Hydrology, Edinburgh, Scotland, 2012.

OECD: Environmental Performance of Agriculture in OECD Countries since 1990, ISBN 978-92-64-04092-2, avaukabke at: http://www.oecd.org/dataoecd/61/21/44254899.pdf, OECD, Paris, France, 2008.

Oenema, O., Bleeker, A., Braathen, N. A., Budnakova, M., Bull, K, Cermak, P., Geupel, M., Hicks, K., Hoft, R., Kozlova, N., Leip, A., Spranger, T., Valli, L., Veldhof, G., and Winiwarter, W.: Nitrogen in current European policies, in: The European Nitrogen Assessment, edited by: Sutton, M. A., Howard, C. M., Erisman, J. W., Billen, G., Bleeker, A., Grennfelt, P., Grinsven, H., and Grizzetti, B., Chapter 11, p. 62-81, Cambridge University Press, 2011.

Pedersen, R. M. H.: Development in Agricultural Nitrogen Surplus compared with the Amount of supplied Animal Manure Study of selected Farms in a Danish Agricultural Landscape from 1998 to 2008, Bachelor project report, 38 p. Aarhus University, November 2011.

PlanteInfo: $\quad$ server=172.23.173.222\& $\quad$ port $=5007 \&$ pi menu=1\&Fuzz=719, http://www.planteinfo.dk/Vejret/2008/ index.asp? itemid=649\&appl=0\&sessionid=DTzWYlw9M52\&, accessed: 14 June 2012, 2012.

Schelde, K., Cellier, P., Bertolini, T., Dalgaard, T., Weidinger, T., Theobald, M. R., and Olesen, J. E.: Spatial and temporal variability of nitrous oxide emissions in a mixed farming landscape of Denmark, Biogeosciences, 9, 2989-3002, doi:10.5194/bg-92989-2012, 2012.

Shingo, H. and Kiyotada, H.: Variability in environmental impacts during conversion from conventional to organic farming: a comparison among three rice production systems in Japan, Journal of Cleaner Production, 28, 101-112, 2012.

Skiba, U., Dick, J., Storeton-West, R., Lopez-Fernandez, S., Woods, C., Tang, S., and vanDijk, N.: The relationship between $\mathrm{NH}_{3}$ emissions from a poultry farm and soil $\mathrm{NO}$ and $\mathrm{N}_{2} \mathrm{O}$ fluxes from a downwind forest, Biogeosciences, 3, 375-382, doi:10.5194/bg-
3-375-2006, 2006.

Smil, V.: Nitrogen in crop production: an account of global flows, Global Biogeochem. Cycles, 13, 647-662, 1999.

Sonneveld, M. P. W., Schoorl, J. M., and Veldkamp, A.: Mapping hydrological pathways of phosphorus transfer in apparently homogeneous landscapes using a high-resolution DEM, Geoderma, 133, 32-42, 2006.

Spiess, E.: Nitrogen, phosphorus and potassium balances and cycles of Swiss agriculture from 1975 to 2008, Nutrient Cycling in Agroecosystems, 91, 351-365, 2011.

Strudsholm, F., Nielsen, E. S., and Flye, J. C.: Fodermiddeltabel 1997. Sammensætning og foderværdi af fodermidler til kvæg, Report, 69, 53 p., Danish Extension Service, Skejby, 1997.

Sutton, M. A., Nemitz, E., Erisman, J. W., Beier, C., Butterbach Bahl, K., Cellier, P., de Vries, W., Cotrufo, F., Skiba, U., Di Marco, C., Jones, S., Laville, P., Soussana, J. F., Loubet, B., Twigg, M., Famulari, D., Whitehead, J., Gallagher, M. W., Neftel, A., Flechard, C. R., Herrmann, B., Calanca, P. L., Schjoerring, J. K., Daemmgen, U., Horvath, L., Tang, Y. S., Emmett, B. A., Tietema, A., Peñuelas, J., Kesik, M., Brueggemann, N., Pilegaard, K., Vesala, T., Campbell, C. L., Olesen, J. E., Dragosits, U., Theobald, M. R., Levy, P., Mobbs, D. C,. Milne, R., Viovy, N., Vuichard, N., Smith, J. U., Smith, P., Bergamaschi, P., Fowler, D., and Reis, S.: Challenges in quantifying biosphereatmosphere exchange of nitrogen species, Environ. Pollut., 150, 125-139, 2007.

Theobald, M. R., Akkal, N., Bienkowski, J., Bleeker, A., Boegh, E., Boissy, J., Braban, C. F., Dalgaard, T., Decuq, C., Dragosits, U., Drouet, J.-L., Durand, B., Durand, P., Fauvel, Y., Flechard, C., Frumau, K. F. A., Hamon, Y., Hensen, A., Janku, K., Kedziora, A., Kulek, B., Magliulo, E., Magliulo, P., Masson, S., Maury, O., Nowak, M., Olesen, J. E., Oliva, M., Palumbo, I., Pugesgaard, S., Schelde, K., Szczepanski, M., Vitale, L., Vogt, E., Sutton, M. A., and Cellier, P.: Strategies for measuring flows of reactive nitrogen at the landscape scale, Nitrogen \& global change key findings - future challenges, Conference proceedings, Edinburgh, 11-15 April 2011, S12-1, 2011.

Tress, B., Tress, G., Fry, G., and Opdam, P.: From Landscape Research to Landscape Planning: Aspects of Integration, Education and application, Springer Verlag, Dordrecht, The Netherlands, 2006.

Ullrich, A. and Volk, M.: Influence of different nitrate-N monitoring strategies onload estimation as a base for model calibration and evaluation, Environ. Monit. Assess., 171, 513-527, 2010.

United Nations Populations Fund: People and Possibilities in a World of 7 Billion. UNFPA, New York, http://foweb.unfpa.org/ SWP2011/reports/EN-SWOP2011-FINAL.pdf, 124 p. 2011.

van Grinsven, H. J. M., ten Berge, H. F. M., Dalgaard, T., Fraters, B., Durand, P., Hart, A., Hofman, G., Jacobsen, B. H., Lalor, S. T. J., Lesschen, J. P., Osterburg, B., Richards, K. G., Techen, A.-K., Vertès, F., Webb, J., and Willems, W. J.: Management, regulation and environmental impacts of nitrogen fertilization in Northwestern Europe under the Nitrates Directive; a benchmark study, Biogeosciences Discuss., 9, 7353-7404, doi:10.5194/bgd9-7353-2012, 2012.

Vogt, E., Braban, C. F., Dragosits, U., Theobald, M. R., Billett, M. F., Dore, A. J., Tang, Y. S., van Dijk, N., Rees, R. M., McDonald, C., Murray, S., Skiba, U. M., and Sutton, M. A.: Estimation of nitrogen budgets for contrasting catchments at the landscape 
scale, Biogeosciences Discuss., 9, 8989-9028, doi:10.5194/bgd9-8989-2012, 2012.

Volk, M., Liersch, S., and Schmidt, G.: Towards the implementation of the European Water Framework Directive? Lessons learned from water quality simulations in an agricultural watershed, Land Use Policy, 26, 580-588, 2009.
Wohlfart, T., Exbrayat, J.-F., Schelde, K., Christen, B., Dalgaard, T., Frede, H.-G., and Breuer, L.: Spatial distribution of soils determines export of nitrogen and dissolved organic carbon from an intensively managed agricultural landscape, Biogeosciences, 9, 4513-4525, doi:10.5194/bg-9-4513-2012, 2012. 